\title{
A Model for Managing the Performance of CMMS Deployment in High-Rise Office Buildings: A View from Lagos, Nigeria
}

\author{
Shamsudeen Musa $\mathbb{D D}^{1}$ Zairul Nisham Musa $\mathbb{D}^{2},{ }^{2}$ and Shirley Jin Lin Chua $\mathbb{D}^{3}$ \\ ${ }^{1}$ Faculty of Built Environment, University of Malaya, Kuala Lumpur 50603, Malaysia \\ ${ }^{2}$ Department of Estate Management, Faculty of Built Environment, University of Malaya, Kuala Lumpur 50603, Malaysia \\ ${ }^{3}$ Department of Building Surveying, Faculty of Built Environment, University of Malaya, Kuala Lumpur 50603, Malaysia
}

Correspondence should be addressed to Shirley Jin Lin Chua; shirleychua88@um.edu.my

Received 6 April 2021; Revised 6 August 2021; Accepted 25 October 2021; Published 16 November 2021

Academic Editor: Tianshou Ma

Copyright (C) 2021 Shamsudeen Musa et al. This is an open access article distributed under the Creative Commons Attribution License, which permits unrestricted use, distribution, and reproduction in any medium, provided the original work is properly cited.

\begin{abstract}
The development of high-rise buildings is a current trend in developed cities to answer the challenges of population growth, adding aesthetic value, and optimal use of land. Lagos particularly is one of the fastest growing cities in the world with Gross Domestic Product (GDP) and Internally Generated Revenue (IGR) in Nigeria, which suggests the need for multiple complex buildings, and the need for their maintenance cannot be overemphasised. This maintenance aspect requires tremendous work due to the complexity attached and several strategies springing up. Different studies reveal that both performance measurements and factors are essential aspects in evaluating maintenance management. Thus, this study seeks to explore performance elements that could improve maintenance. Personnel attitude, maintenance policy, maintenance review, and maintenance implementation were measured relative to computerised maintenance management system (CMMS) performance. With a random sampling technique, a sample of 134 Facility Management (FM) practitioners involved in high-rise office buildings was used to assess the effects of CMMS deployment. Results were analysed by Partial Least Squares Structural Equation Modelling (PLS-SEM). Findings from this study highlighted an indirect effect size and a large predictive relevance of personnel attitude as a critical factor for a smooth maintenance execution procedure of $12.59 \%$ and a standard operating procedure (SOP) of $15.64 \%$ on maintenance implementation to contribute $28.36 \%$ to performance. This paper uncovers the place of personnel attitude in determining effective maintenance.
\end{abstract}

\section{Introduction}

Users and owners of buildings are demanding better performing buildings in order to maximise their performance output. Facility managers continue to deal with these contending requests all the time and try to incorporate the necessary services to enhance the management of the built assets for a successful business operation [1-3]. There is also pressure to preserve existing building facilities to meet the growing demands of business operations as building elements require adequate care to limit exposure to deterioration and prevent the unexpected breakdown of elements [4]. The activities involved in this management process are complex, comprising the interaction of technical, financial, social, and legal factors that govern the use of buildings in transforming the inputs of people, energy, materials, and technology to achieve the desired objectives [5]. The extensive cost involved to achieve these complex interactions has been argued over the years as part of the justifications for neglecting building maintenance programs [6], specifically in high-rise buildings that are synonymous with maintenance complexities and issues such as costs, time, lack of tools, unskilled workforces, insufficient guideline, and many more. Hence, increased breakdown arises, causing interruption to performance activities for building users. Many times, people fail to realise that maintenance contributes to the performance of an organisation in terms of income from property lease or owning the building in addition to the 
environment, quality, and safety as other performance factors [7], generally, when measuring maintenance performance of a high-rise building in particular, due to the accident-prone nature of buildings to personnel, the unsafe environment, and its complex nature [8]. Armstrong [9] posited that one should consider both quantifiable parameters and the quality of performed maintenance within the organisation. The growing significance of building maintenance has generated an increasing interest in developing efficient maintenance procedures to improve performance. This has changed the maintenance operations and repair of building equipment, especially with regard to technical and optimisation of physical assets. Many organisations are now aware of the effectiveness offered by technology in failure prevention and its consequences, which may result in total production shutdown, loss of customers, personnel unemployment, and reduction of market share [10]. Therefore, literature on maintenance emphasises more the effectiveness of systems such as CMMS for effective and reliable service delivery.

The new trend of maintenance practices is progressing towards a very complex environment known as repair engineering, which requires organisations to assess the systems from a wider perspective [11]. The main highlight of this trend drives organisations to lessen expenditures on "noncore" activities. To attend to these multiple tasks that are inclined with the growing trends in productivity and efficient maintenance that meet up with world-class standards and global competitiveness, the application of automated systems cannot be overemphasised. Over the years, studies have proven that CMMS is synonymous with productivity and helps management in making informed decisions considering the complex relationship between cost and benefit in today's marketplace [12]. Specifically, CMMS are computer application software, which help organisations in running their maintenance activities efficiently. With CMMS utilisation, organisations can schedule preventive maintenance, manage corrective maintenance, keep track records of machine hours and warranty periods, manage spare parts utilisation and inventory tracking, and monitor personnel activities [13]. Advancements in CMMS have been tailored towards Building Information Modelling (BIM), ARCHIBUS to integrate pre- and postconstruction project planning tools, accounting, mobile solution, Geographic Information System (GIS), Enterprise Resource Planning (ERP) systems (Oracle, SAP, etc.), and other functions $[14,15]$. CMMS plays a fundamental role in solving the problem of huge maintenance data accumulated in the organisation database to help the personnel execute their jobs more effectively [16]. However, many organisations see CMMS as a strategy rather than a tool for FM [10]. Despite its outlined importance, statistics presented a poor implementation even in a well-resourced organisation; successful implementation is estimated at about $25-40 \%$, while only $6-15 \%$ were estimated to use CMMS in full capacity. This is tied to the unreadiness of the organisation, failure to sell the benefits of CMMS to users, inadequate Internet infrastructure, and resources to carry out the process [15]. Since CMMS assembles information as its core function and the facility managers core interest is on information monitoring, a perfect match is demonstrated, which are challenging in practice. These have necessitated the facility managers to improve their obligation to adapt according to its associated trends from time to time $[17,18]$.

In response to these advancements, the development of high-rise buildings became evident. When considering the high land value in cities, the development of high-rise buildings is not only efficient but also the most economical. Utilising a single plot with multiple buildings, Klaber [19] described it as a critical factor for making an increasing return of investments. The development of high-rise buildings in urban cities is described as a response to rapid urbanisation and population growth and adding aesthetic values to metropolitan cities development [20]. In fact, it is almost impossible to manage the maintenance activities of high-rise buildings effectively without CMMS due to its highlighted significance on business profitability. Basically, high-rise buildings have no universal definition. Council of Tall Buildings and Urban Habitat (CTBUH) describes highrise buildings as buildings whose height requires different design and construction conditions, including its use, compared to those exist in common buildings [21]. National Fire Protection Association [22] described a high-rise building as a building where the floor of an occupiable storey is greater than 75 feet $(23 \mathrm{~m})$ above the lowest level of the fire department vehicle access, a storey building with unreasonable evacuation time in the event of a fire outbreak, and a building that is beyond the reach of the fire department's longest ladder constructed for human habitation. Aliyu et al. [23] noted that the definition of a high-rise building in Nigeria is similar to that in the context of British Standard (BS). The development of high-rise office buildings is indispensable in urban cities [20]; it is considered the most efficient and very economical if properly maintained. This situation is true in Lagos, Nigeria, being the study area.

In developing countries, studies have identified several shortcomings within the FM sector, particularly in high-rise buildings due to the highlighted maintenance complexities and with regard to equipment provision, adequacy of funds, personnel attitudes, and so on. For instance, Kamaruzzaman et al. [24] noted the position of office buildings in Malaysia, Abd et al. [25] observed the residential situation in Malaysia, Amankwah et al. [26] observed the residential situation in Ghana health sector, Faremi et al. [27] observed the residential situation in Nigeria banking sector, and Ajayi and Adenuga [28] observed the residential situation in Nigeria health sector. Still, the aspect of maintenance is regarded mainly as a tactical role. However, many organisations have no clear objectives for their maintenance activities, which together with strategies form the driving force for improving maintenance effectiveness [29]. In Nigeria, literature has shown interesting discussions on maintenance situations within a similar context of other developing countries; few studies have examined the underlying drivers and theoretical frameworks of the low response of CMMS [27, 30-33]; the market popularity of CMMS flourishes within the private sector than the public sector, while other interesting findings pointed towards the ill maintenance culture and the attitude 
of FM professionals in [34, 35]; facility managers were generally less involved in the strategic tasks; the FM title is used as a "catch phrase" to improve patronage as they do not adopt FM principles in actual practice $[36,37]$. The application of CMMS certainly offers the possibility of optimising preventive maintenance operations. Hence, it becomes imperative to identify the effects of different elements along with personnel attitudes as part of an ongoing doctoral research to propose a CMMS implementation framework for maintenance management service delivery in Nigeria.

\section{Literature Review}

2.1. Performance Measurement. This section introduces the background that informed the theoretical concept on which this study is established. Performance measurement has been viewed as a vital element in strategic thinking by stakeholders. Besides, it becomes difficult to improve or control the maintenance process without a proper performance measurement system [38]. Management practices have experienced innovation, organisations have downsized, and companies have consciously trained and retrained personnel. These have changed the way organisations handle activities to consider outsourcing and focus on core activities [39]. Constant evaluation of maintenance performance remains critical to reducing downtime, efficient service, and optimum resources [40-42]. When considering maintenance management, Nutt and McLennan [43] explain that the first step is performance measurement because it gives direction to the improvement process. Myeda et al. [5] noted that several frameworks had been established over the years to measure performance. However, until 1980, performance measurement was mainly financial measures based such as internal processes, customer, innovation, and learning [44, 45]. This does not capture the necessity to support effective maintenance operations. As academic researchers and managers tried to rectify these inadequacies in the current approaches to performance measurement, some however focused on personnel that carry out the maintenance operation for the organisation to flourish and become relevant [46], while others' focus was based on improving operational measures such as cycle time and defects rate $[47,48]$. The revelation shows that a single measure cannot provide clear and adequate performance targets; rather, organisations should focus on critical aspects of the business [44]. Further, in Kaplan and Norton [44], to balance performance measures, the scenario was viewed as the indicators and controls in the cockpit of an airplane. For safe navigation of the airplane, the pilots are interested in detailed information on altitude, fuel, air speed, bearing destination, and tons of other indicators that determine the estimated arrival success. Similarly, in performance measurement, an organisation requires views from several areas concurrently.

In the last few decades, significant attention has been channelled from practitioners and researchers about what and how to measure performance in a cost-effective and practical situation. However, various studies have demonstrated that frameworks incorporating intangible assets and nonfinancial measurements have achieved competitive advantages [5]. In essence, the most beneficial function of performance measurement is noted in the study by Atkinson et al. [49] to coordinate, monitor, diagnose, and pinpoint problem areas, including necessary actions that will give the best impression on overall business performance. If well implemented, the effect of performance measurement will propel organisation effectiveness. To achieve this, the performance measurement must be aligned with organisational strategies and structure. The strategic goals of an organisation become effective by setting some performance indicators at all levels to enable an organisational framework to achieve its performance measurement.

2.1.1. Maintenance Performance Indicators. Maintenance performance indicators are basically used for performance measurement of maintenance. Performance indicators precisely are indicators of performance [50]. An indicator is a product of several metrics (measure) that is used for the measurement of maintenance performance in an organisation [38]. Performance indicators generally are "sets of values against which to measure" to demonstrate how effectively an organisation is achieving its business objectives [51]. Most organisations engage in common performance measures that leave the gap of inconsistencies. The significance of performance measurement should be viewed as a broader perspective to determine job satisfaction with regard to theories of motivation. To measure the efficacy of the service, it is crucial to understand the present conditions and postulate modifications in management practices to achieve the required performance [52]. In situations where service delivery is evaluated using measures that are mismatched with the present-day context, it creates a barrier and gap between users' needs and expectations since human efforts cannot completely be replaced with machines irrespective of advanced technology and computer capabilities [53]. Most advanced countries have made efforts to manage these situations effectively through strict compliance with regulations [54]. Amankwah et al. [26] and Afonja et al. [55] noted that a lot of developing countries are fraught with obstacles that pose major risks to maintenance personnel and not leaving the immediate environment and community as a whole. The tools for this evaluation to check service delivery against the planned activities are key performance indicators [56]. It is therefore necessary to highlight some essential predictors of successful performance measurement.

2.2. Important Supportive Organisational Elements. An extensive review of previous studies on CMMS and measurement of performance shows that several supportive organisational indicators, including policy structure, resources, management, and personnel involvement, may predict effective maintenance service delivery [10, 57-59]. These characterisations are discussed in the following.

2.2.1. Maintenance Policy. It has been established that, for impactful maintenance to be achieved, the need for government regulation/legislation and national policies that 
provide a legal framework governs the description and maintenance implementation where a nonconformity should attract adequate penalties $[60,61]$. In situations where some parts of maintenance are outsourced, the policy describes the service level agreement (SLA) and activities covered in relation to strategic planning. The process of work identification and strategic planning was discussed in [62]. Maintenance policy is written documents, including a set of guidelines or rules that provide a management framework to the maintenance personnel to determine appropriate maintenance strategy and standards in the organisation [60]. The popular maintenance policies, including conditionbased maintenance (CBM), failure-based maintenance (FBM), and corrective maintenance (CM), are in this category. The three important elements for policy formulation are the choice of maintenance strategy, maintenance standard required, and maintenance resource allocation. Unrealistic elements and inappropriate metrics can be identified, and improvements can be made through policy improvements. These elements determine the success of every planned or unplanned maintenance activity [60].

(1) Maintenance Identification. Work identification is a key to determining equipment reliability. "If you are not identifying the proper work, then the rest of your practices are irrelevant" [16]. Interestingly, in most organisations, the data needed to improve equipment reliability are always available scattered around the organisation, which are yet to be put together into a central repository for ease of analysis and turned into actionable information for decision-making [16].

(2) Service Level Agreement (SLA). The SLA defines the commitment between a client and a service provider. Mohamed et al. [39] stressed that it is a mechanism set up by the government or an organisation to assist performance management of outsourced services in FM. This document spells out services that must be complied with according to the standard to ensure that the FM provides quality standards as stipulated in the agreement [39].

(3) Strategic and Priority Plan. An organisation's process of identifying direction or strategy and appropriate resource allocation to pursue the strategy is considered a strategic plan. With the globalisation of markets, competition and demand for higher quality products are evident. One way to achieve this is the elimination of waste due to breakdowns and machine failures. To minimise this waste, the organisation must adopt a maintenance strategy that will incorporate a balance between planned maintenance and or unplanned maintenance to meet statutory requirements, including technical or operational reliability considerations to preserve the office building and prolong its fiscal life $[57,63]$.

2.2.2. Maintenance Implementation. This aim is to identify and implement improvement action on equipment in service [64] and technical guidelines to provide effective
Standard Operating Procedures (SOPs) as spelt out in maintenance policy [65]. However, the implementation constitutes and relies on several resources (equipment, manpower, spare part, and materiel), strategies, failure and downtime, predetermined interval, data acquisition, monitoring, and advanced technology levels to avoid unexpected stoppages [66-68]. These have been used interchangeably in different ways by different authors [69]. Nevertheless, many organisations still experience excess failure-mediated downtime, with overall equipment effectiveness (OEE) around $50 \%[70]$.

(1) Standard Operating Procedure (SOP). SOP comprises steps, decisions, and actions to be performed in response to maintenance events, which may include a particular set of conditions. Building facilities may have a separate SOP (or set of SOPs) in place for each number of events that takes place. The CMMS may be configured to employ several SOPs for different possible events, for instance, intruder detected and access to an area denied. SOP basically depend on the knowledge or experience of its designer [71].

(2) Maintenance Execution Procedure. Departments/units/ sections are compulsory to develop a maintenance work program that covers all building facilities. Expectedly, this maintenance work program support designed maintenance strategies and a balance of (planned and unplanned) maintenance activities and focus on service deliveries, maintenance priorities, resources available, and performance management [72, 73]. The line of procedure of scheduled works and works on demand should be in accordance with the maintenance designed program. The Details of different elements that must be incorporated to balance the maintenance works program are discussed in [58].

(3) Backlog and Priority Control. When considering effective maintenance management, an incredible element is a backlog to maintain maintenance efficiency. This backlog manages the necessary workload and manpower in the organisation. It describes all approved maintenance works but are yet to be completed and helps management to make informed decisions on overtime, task allocation, recruitment, and subcontracting. Backlog can be a preventive or predictive maintenance activity since its primary aim is to make sure that critical assets do not break down and prevent work orders that are not ready to be scheduled. The priority system allows the maintenance backlog to filter out maintenance work that requires emergency attention and explains work orders that must be prioritised to ensure the greatest possible uptime of all facilities [74].

\subsubsection{Maintenance Review}

(1) User's Feedback. User feedback is extremely useful in assisting maintenance organisation in improving their services. The concept of user's feedback is explained in Stokic et al. [75] and Syafar and Gao [76] as empowering 
management that allows off-site notifications and live feeds that allow management to take the right and informed maintenance decisions to improve on maintenance performance. Generally, one interface is opened to users to receive opinions, critiques, and suggestions, which are valuable information to improve maintenance service delivery [77-79].

(2) Workforce Utilisation and Skill Level. The importance of service delivery is expanding and emphasising the necessity for well-designed and run service systems [80]. The turbulent business environment has resulted in stiff competition among organisations which has resulted in a reduced workforce. Campbell [81] noted that workforce utilisation could be challenging to match supply and demand, particularly in a labour-intensive organisation where most services cannot be inventoried; they must be delivered in accordance with the needs' timing, which can be extremely changeable. The benefits, limitations, impediments, and strategies of workforce utilisation are discussed in [81-84].

(3) Mean Time between Failure. The MTBF is a system reliability parameter to measure how long a component is expected to run smoothly; this is always required to enhance the overall availability. Parida and Kumar [45] explain the various concepts proposed by various researchers for performance measurement even though some of these concepts used in defining maintenance metrics remain unclear about what to measure and how to communicate the maintenance performance to organisational goals. It is usually measured over a period that includes multiple failures, either multiple failures of a single asset or single failures of multiple assets of the same type, expressed in hours to help with inventory planning, scheduling maintenance, and system design [85].

(4) Equipment Records. To increase the quality of service, which is a measure of maintenance performance, successful maintenance obviously necessitates effective documentation. "If it is not written down, it did not happen!" [86], which are essentials of good maintenance practice. Equipment records include details of work completed with maintenance costs, as well as work done while the job was in progress. A historical profile method is used to classify such expenditures. Other data include operations, service manuals, drawings, and warranties.

(5) Regulatory Compliance. Regulatory compliance standards are becoming more stringent, posing new problems for businesses in many organisations. Sadiq and Governatori [87] described compliance as a process of ensuring that organisations follow a set of prescribed and/or agreed-upon guidelines. In this way, legislative and regulatory authorities may impose compliance obligations (e.g., ISO 9000). The most important objective of regulatory compliance is in the strategic alignment of business process management initiatives.
(6) Mean Time to Repair (MTTR). MTTR is a basic measure of the maintainability of repairable items. It signifies the duration in which equipment is out of production or the average time taken to repair/fix a failed equipment. The estimation is shown as follows: MTTR = total downtime periods $\div$ number of downtime periods.

2.2.4. CMMS Performance. Generally, the essence of applying a CMMS is to manage complex maintenance systems, with precise investigation and implementation in an organisation to optimise costs and idle times [88]. CMMS skills became greater than before and provided fundamentals of performance measurement for elements that impact organisational objectives, evaluation, and management control. Organisations recognise the importance of CMMS as a tool for enhancing service quality as they are developed to significantly support documentation control following ISO 9001:2008 [89]. Explanations of performance measurement may be based on an assumption about the need to measure. Performance measures remain a necessity for success in organisations. It is the process of reporting, analysing information on behaviours of a person, a group of people, or an organisation before and after the tasks for productivity enhancement. Rudiments of performance measurement discussed previously in this study uphold the same position with Parker [90] that the reasons for performance measurement clearly vary from one another even though basic measures surround service quality, proportioned of planned versus achieved maintenance, and overall equipment efficiency (OEE).

(1) Service Quality. Cupello [91] classified the performance indicators into two aspects which are satisfaction factors from (customer and employee) and (performance of project and suppliers). In recent times, service quality is defined as a comparison of a perceived service versus perceived expectations and its perceived performance which have been argued in several studies as a primary measure of performance [5, 92-94].

(2) Proportion of Planned versus Achieved. Some literature may refer to it as a percentage of planned maintenance. It describes the percentage of maintenance time spent on planned maintenance works as a percentage of overall maintenance hours in a given period of time. This indicator monitors if the tasks are being performed (if the planning took place or if the scheduled work was completed on time) against the results that have been achieved (the number of failures and downtime), which are linked with work identification, work planning, scheduling, work execution, and schedule compliance [95].

(3) Overall Equipment Efficiency (OEE). The OEE evaluates how equipment is effectively utilised. OEE calculation is centred on the three factors:

Availability $=$ run time/planned production time. 
Performance $=($ ideal cycle time $\times$ total count $) /$ run time.

Quality $=$ good count/total count.

CMMS makes it easy to track an informed improvement over a period of time, such as a data-driven picture of how effective the maintenance procedures are running according to critical factors such as availability, performance, and quality of equipment. OEE calculation for a piece of equipment is given as follows:

$$
\mathrm{OEE}=\text { availability } \times \text { performance } \times \text { quality } .
$$

2.2.5. Personnel Attitude. The attitude of personnel is an important indicator to performance measurement and may at some point lead to unexpected and costly equipment failures and sometimes with adverse effects on people and the environment if not put into consideration [53]. Studies have agreed that the activities of humans cannot be completely substituted with computers regardless of the advancement in technology [53]. The need to involve personnel is maintained since the success of their operations and processes is the success rate received by the organisation. Thus, getting them involved will not only result in dedication to efficient performance measurement but also impact the actual performance [96]. To Eagly and Chaiken [97] and Asiedu et al. [46], attitude may be influenced by many factors from both internal and external such as behaviour, consistency, motivation, efficacy, belongingness and many more. The understanding of personnel attitude dwells more in the field of social psychology, yet study on attitudes has shared endeavour within the social sciences, mainly with marketing, sociology, and so on. Many of these have changed the relationship between personnel and the organisation, including other stakeholders [49]. In some cases, manpower operations were replaced with computers for efficient transition. All these have not completely solved the barriers to measuring intangible resources, which leaves a gap in all innovations done.

(1) Efficacy. In psychology and many other fields, the phrase "self-efficacy" has become widely used. Several studies have noted in many ways that a strong sense of effectiveness improves human achievement and personal well-being $[98,99]$. Bandura and Wessels [98] noted that people who are confident in their talents view tough jobs as challenges to overcome rather than dangers to avoid. This understanding eliminates anxiety, phobic behaviour, and nightmares. Evidently, self-efficacy significantly measures the attitude of personnel.

(2) Belongingness. A highly delighted and satisfied person is considered very crucial to achieving success in any organisation [46]. Similarly, peer affiliation has also been linked to self-esteem and mood, as well as stress reduction and the facilitation of social contact and friendships [100]. Studies have noted that belongingness may interact with overall well-being, feelings, and loneliness which offered a direct connection with the attitude of personnel in any organisation $[46,100,101]$. The positives include enhanced feelings of devotion, belongingness, and stability. On the basis of this logic, one could argue that employees with low affective commitment will choose to leave an organisation, while employees with a high and positive affective commitment will stay for longer periods, as they believe in the organisation and its mission [102].

(3) Behaviour Change. Building managers, according to Elmualim et al. [103], are at the forefront of organisational behaviour change and in a position to influence personnel working in businesses, government departments, and public services. In behaviour change of people, training exercises will be organised periodically. The metrics of measurement on how well the exercise is can be based on the numbers done, how comprehensive the training was, and its effect on behaviour change.

Therefore, to develop an effective performance measurement in this study, contributions from various authors (Table 1) suggested that the purpose, methods, time frame and timing, improvements and reviews, and factors to measure will drive the effective maintenance. However, many of these factors constitute general conditions of performance measurement.

2.3. Development of the Theoretical Framework. In the figure below, a theoretical framework relating characteristics of maintenance policy and maintenance implementation towards CMMS performance is presented. The framework builds on the existing argument that the primary focus of FM is achieving the business core objectives. Based on this understanding, the value of successful CMMS deployment in high-rise office buildings is determined. Maintenance policy, as presented in the framework, represents the guidelines or rules for the identified maintenance activities and determines appropriate maintenance strategy and standards to be used by personnel in relation to outsourcing maintenance activities, while the maintenance implementation drives the execution of the maintenance management. These elements of maintenance management have been viewed and used interchangeably by different authors in different ways [69]. Hence, the elements of maintenance management adopted in this research follow the position of $[58,71]$. A significant number of studies have demonstrated that human efforts are indispensable even with CMMS. The aspects of personnel attitude are determined through belongingness and efficacy following the basis of [46], which has described humans as an individual and considered their membership in a particular group to be most important. This is because social identity remains a fundamental aspect of what becomes a human. In that, all personnel want to feel and be accepted in the organisation they belong to. This aspect is measured both directly and indirectly. The use of direct and indirect relationships follows the position of $[138,139]$, which noted that the propagative mechanism is capable of influencing the dependent variable through the independent variable. As shown in the figure, the forward arrows present the 
TABLE 1: Important supportive organisational elements.

\begin{tabular}{|c|c|c|}
\hline Observed variables & Reference & Acronyms \\
\hline Maintenance implementation & $\begin{array}{l}\text { Koussaimi et al. [64]; Queensland Government [58]; Raveenthiran [59]; Baaki } \\
\text { et al. [65]; Liptrot and Palarchio [104]; Lee and Scott [60]; Horner et al. [69]; } \\
\text { Lundgren et al. [70] }\end{array}$ & \\
\hline (i) Maintenance strategies & Fredriksson and Larsson [105]; Horner et al. [69] & Pr1 \\
\hline (ii) Maintenance labour & Olanrewaju and Abdul [68]; Raveenthiran [59] & $\operatorname{Pr} 2$ \\
\hline $\begin{array}{l}\text { (iii) Maintenance equipment and } \\
\text { technique }\end{array}$ & Olanrewaju and Abdul [68]; Molochnikov et al. [106] & Pr3 \\
\hline (iv) Failure and downtime & Engeler et al. [107]; Márquez [57] & Pr4 \\
\hline (v) Predetermined interval & Raveenthiran [59] & $\operatorname{Pr} 5$ \\
\hline (vi) Monitoring and inspection & Raveenthiran [59] & Pr6 \\
\hline (vii) Acquisition of maintenance data & Márquez [57] & $\operatorname{Pr} 7$ \\
\hline (viii) Maintenance manager & Crespo and Gupta [108]; Ruparathna et al. [109]; Raveenthiran [59] & Pr8 \\
\hline (ix) Spare parts and materials & Márquez [57]; Oliveira et al. [110] & Pr9 \\
\hline Backlog and priority control & Mike [74]; Jandali et al. [111] & \\
\hline (i) Maintenance log report & Mike [74] & BCPS1 \\
\hline (ii) Asset hierarchy & Raveenthiran [59]; Mike [74] & BCPS2 \\
\hline (iii) Centralised asset control & Balouei et al. [10]; Mike [74]; Raveenthiran [59] & BCPS3 \\
\hline (iv) Mobile friendly solution & Mike [74] & BCPS4 \\
\hline $\begin{array}{l}\text { (v) Condition monitoring sensors and } \\
\text { barcode lookup }\end{array}$ & Mike [74] & BCPS5 \\
\hline
\end{tabular}

Execution procedure

Queensland Government [58]; Muchiri et al. [112]; Pintelon and Van Wassenhove [113]

(i) Efficient work order

(ii) Job scheduling

(iii) Breakdown

(iv) Time

(v) Usage

(vi) Condition

(vii) Event

Standard operating procedure

(i) Define maintenance reason

(ii) Define location

(iii) Define coding

(iv) Who is responsible

(v) Define asset and criticalities

(vi) Define material usage

(vii) Define workflow procedure

(viii) Evaluation of job done

Service level agreement

(i) Type of service to be outsourced

(ii) Disruption periods

(iii) Reliability and responsiveness of service provider

(iv) Consequences for not meeting deadline

(v) Procedure for reporting issues with the service

Strategic plan

(i) Asset priority

(ii) Operating cost

(iii) Maintenance cost

(iv) Element hierarchy

Maintenance ID

(i) Type of use

(ii) Age of building

(iii) Material type

(iv) Exposure to nature or other factors

Raveenthiran [59]; Queensland Government [58]; Muchiri et al. [112]; Gado and SamehHussien [114]

Pintelon and Van Wassenhove [113] MEP2

Keneley [115]; Raveenthiran [59] MEP3

Raveenthiran [59]

Raveenthiran [59]

Queensland Government [58]

Queensland Government [58]

Libal et al. [71]

Libal et al. [71]

Libal et al. [71]

Libal et al. [71]

Libal et al. [71]

Libal et al. [71]

Libal et al. [71]

Libal et al. [71]

Libal et al. [71]

MEP4

MEP5

MEP6

MEP7

Mohamed et al. [39]; Verma [116]

Mohamed et al. [39]

Mohamed et al. [39]

SOP1

SOP2

SOP3

SOP4

SOP5

SOP6

SOP7

SOP8

Mohamed et al. [39]

OM1

OM2

Mohamed et al. [39]

OM3

Mohamed et al. [39]

OM4

OM5

Edirisinghe et al. [117]; Márquez [57]; Raveenthiran [59]

Ismail [118]; Raveenthiran [59]

STP1

Raveenthiran [59]; Márquez [57] STP2

Edirisinghe et al. [117]; Márquez [57] STP3

Raveenthiran [59]

Liptrot and Palarchio [104]; Queensland Government [58]; Raveenthiran [59]

STP4

Raveenthiran [59] MID1

Raveenthiran [59] MID2

Raveenthiran [59] MID3

Raveenthiran [59]

MID4 
TABle 1: Continued.

\begin{tabular}{|c|c|c|}
\hline Observed variables & Reference & Acronyms \\
\hline Personnel attitude & $\begin{array}{l}\text { Adetoro and Damilola [34]; Harrison et al. [119]; Saari and Judge [120]; Asiedu } \\
\text { et al. [46]; Eagly and Chaiken [97]; Mohammad et al. [121]; Gouws and Trevelyan } \\
\text { [53]; Kutucuoglu et al. [96] }\end{array}$ & \\
\hline (i) Efficacy & Bandura and Wessels [98]; Maddux and Gosselin [99] & PA1 \\
\hline (ii) Belongingness & Lee and Robbins [100]; Asiedu et al. [46]; Dartey-Baah [101]; Meyer et al. [102] & PA2 \\
\hline (iii) Behaviour change & Elmualim et al. [103] & PA3 \\
\hline Maintenance review & $\begin{array}{c}\text { Dukić et al. [122]; Eyerusalem [123]; Labib [124]; Márquez [57]; Muchiri et al. } \\
\text { [112]; Parida [125]; Parker [90] }\end{array}$ & \\
\hline (i) User's feedback & $\begin{array}{l}\text { Hammami et al. [78]; Stokic et al. [75]; Syafar and Gao [76]; Giannozzi et al. [77]; } \\
\text { Nguyen et al. [79] }\end{array}$ & Per1 \\
\hline (ii) Workforce utilisation and skill level & $\begin{array}{c}\text { Wemmerlöv [80]; Campbell [81]; Brusco and Johns [82]; Burleson et al. [83]; } \\
\text { Stanley [84] }\end{array}$ & Per2 \\
\hline (iii) Mean time between failure & NextTechnik [85] & Per3 \\
\hline (iv) Equipment record & Patel and Chotai [86] & Per4 \\
\hline (v) Regulatory compliance & Sadiq and Governatori [87] & Per5 \\
\hline (vi) Mean time to repair (MTTR) & NextTechnik [85] & Per6 \\
\hline Maintenance policy & Lee and Scott $[60]$ & \\
\hline (i) In-line with national policy & Zubairu [126] & MP1 \\
\hline (ii) Formal training & Baaki et al. [65] & MP2 \\
\hline $\begin{array}{l}\text { (iii) Procedure for meeting schedule with } \\
\text { staff }\end{array}$ & Farahani and Lipsett [127] & MP3 \\
\hline $\begin{array}{l}\text { (iv) Practice and procedure with time } \\
\text { documented }\end{array}$ & Adewunmi et al. [128]; Fraser [129] & MP4 \\
\hline (v) Quality assurance & Asubonteng et al. [92]; Muchiri et al. [112] & MP5 \\
\hline (vi) Record keeping system & Koleoso et al. [36]; Muchiri et al. [112] & MP6 \\
\hline (vii) Review of policy & Márquez [57] & MP7 \\
\hline (viii) Provision of outsourced services & Abdeen and Sandanayake [130]; Toni et al. [131] & MP8 \\
\hline $\begin{array}{l}\text { (ix) Departmental maintenance guideline } \\
\text { and action plan }\end{array}$ & Gandhare et al. [132]; Alzaben [133] & MP9 \\
\hline (x) Schedule for preventive maintenance & Márquez [57]; Eti et al. [134] & MP10 \\
\hline $\begin{array}{l}\text { (xi) Personnel classification affiliating with } \\
\text { the training required }\end{array}$ & Zawawi and Kamaruzzaman [4]; Jardine et al. [135] & MP11 \\
\hline CMMS performance & $\begin{array}{l}\text { Ismail [136]; Balouei et al. [10]; Amankwah et al. [26]; Tumiran [88]; Abdullahi } \\
\text { and wan Yusoff [89]; Parker [90] }\end{array}$ & \\
\hline (i) Service quality & $\begin{array}{l}\text { Cupello [91]; Asubonteng et al. [92]; Haddad et al. [93]; Khan and Tabassum [94]; } \\
\text { Myeda et al. [5] }\end{array}$ & CMP1 \\
\hline (ii) Proportion of planned versus achieved & Panuwatwanich [137]; Muchiri et al. [95] & CMP2 \\
\hline (iii) Overall equipment efficiency & Muchiri et al. [95]; Eyerusalem [123] & CMP3 \\
\hline
\end{tabular}

connection between two constructs, while the double-head arrows show the existence of a relationship. The relationship arrow in this framework exists between the policy and maintenance implementation. To achieve this, the performance of CMMS is measured as the dependent variable relative to the identified independent variable by assigning a performance metric. For instance, training exercises will be organised periodically to effect behaviour change in people. The metrics of measurement on the quality of training exercise can be based on the numbers done and how comprehensive the training was and its effect on behaviour change. This will influence the response time to repair, the proportion of planned maintenance achieved, and the overall equipment efficiency. This framework for the improvement of maintenance management of high-rise office building facilities builds on the arguments of Mishra et al. [140], which has studied the world-class maintenance management framework and is supported by the Queensland Government [58, 123]. The performance assessment is consistent with the position of $[52,141,142]$ that for effective performance assessment, the existence of an active FM will help in identifying potential problems prior to component breakdown. The theoretical framework for this research is presented in the following (see Figure 1).

\section{Methodology}

This study adopted a quantitative approach similar to Amankwah et al. [26]. Ghani et al. [143] noted that the quantitative approach involves gathering numerical data and analysing it using a mathematical method. The study began with the extraction of variables from published literature in relation to maintenance management. The keywords' combination, including "maintenance performance," "maintenance management," "computerised maintenance management system," "high-rise office buildings," "effective building maintenance," "framework for maintenance management," and "attitude towards service delivery," was used to obtain related literature from leading electronic databases, namely, Scopus, Web of 


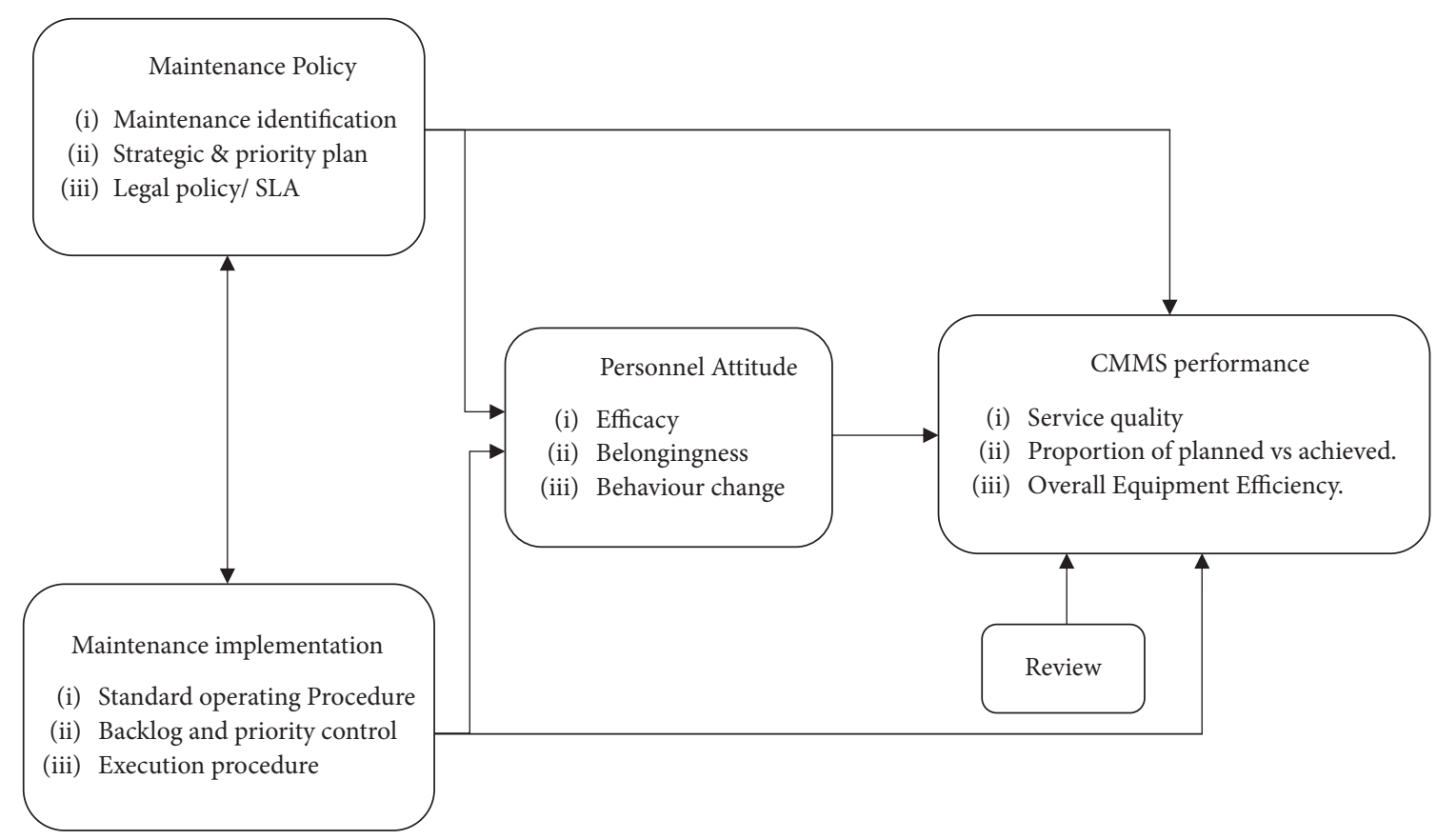

Figure 1: Theoretical framework for CMMS deployment.

Science, and ScienceDirect, and also journals and books. This approach had previously been used by [65]. The information extracted was used to build up the variables incorporated in a quantitative study. Following this, a questionnaire survey was used to obtain data for the study. Surveys are considered efficient for the collection of scientific data from a research population [144]. The questionnaire was designed to be easy to understand [145] and was made up of two parts. Part A consisted of demographic characteristics of the respondents, such as gender, field, educational qualification, and year of experience, while part $B$ sought to obtain information on general maintenance policy information, maintenance implementation, participatory mechanisms, and CMMS performance. The established performance indicators obtained from reviewed literature (see Table 1) were measured using a five-point Likert scale, with 1 being strongly disagree and 5 being strongly agree. The nature of this research required surveying building management professionals in high-rise office buildings in Lagos State, Nigeria. As such, random sampling, which is a probability sampling technique, was deemed to be an appropriate sampling technique for the study as it allowed each element of the population equal opportunity of being included in the sample [146, 147]. To ensure the integrity of the respondents, the target population was made up of registered IFMA members from the Lagos Branch. A total of 520 members were identified, out of which 187 were adjudged to meet the requirements for the study. These were personnel directly or indirectly involved in the maintenance management operations of the high-rise buildings. A total of 137 questionnaires were completed and returned, of which 134 were found to be valid for analysis. The data from the survey were analysed using both descriptive and test statistics. The descriptive analysis was carried out using Statistical Package for Social Sciences (SPSS), while inferential statistics analysis, Partial Least Square Structural Equation Modelling (PLS-SEM), was performed using SMART PLS 3, which signifies the main statistical tool in this study, following the reliability threshold as presented in Table 2. PLS-SEM is an innovative variance-based tool capable of estimating complex path models [148]. Because the nature of performance is based on a theoretical concept that can be understood through measurable indicators, PLS-SEM was considered the most appropriate. The study used PLS-SEM to model the observed variables to estimate the direct, indirect, and joint effects. Based on the author's logical reasoning and the research's predictions, the study proposed a hypothetical model (Figure 2) relating the links between the performance variables. The structural equation modelling, on the other hand, required evaluation of both the measurement and structural models. The research approach for this study is depicted in Figure 3.

3.1. Model Development. Following the categorisation leading to effective maintenance service delivery (Table 1), five elements (maintenance policy, service level agreement, maintenance review, maintenance implementation, and personnel attitude) represent the first order and six elements (standard operating procedure, backlog control, execution procedure, SLA, strategic plan, and maintenance identification) of second-order exogenous constructs were modelled. The CMMS performance represented the dependent variable, which was measured with the three observed variables. Furthermore, the model explores both the direct and indirect relationships between the indicators and CMMS deployment. Specifically, this study postulated two 
TABLE 2: Measurement model for performance of CMMS.

\begin{tabular}{|c|c|c|c|c|c|c|}
\hline & Items & Loading $^{\mathrm{a}}$ & $\mathrm{AVE}^{\mathrm{b}}$ & $\mathrm{CR}^{\mathrm{c}}$ & $\mathrm{CA}^{\mathrm{d}}$ & rho_A $A^{\mathrm{d}}$ \\
\hline \multirow{3}{*}{ Maintenance identification } & MID2 & 0.874 & 0.826 & 0.934 & 0.894 & 0.897 \\
\hline & MID3 & 0.926 & & & & \\
\hline & MID4 & 0.925 & & & & \\
\hline \multirow{2}{*}{ Strategic plan } & STP2 & 0.962 & 0.918 & 0.957 & 0.911 & 0.916 \\
\hline & STP3 & 0.954 & & & & \\
\hline \multirow{4}{*}{ Service level agreement } & OM1 & 0.850 & 0.709 & 0.907 & 0.863 & 0.87 \\
\hline & $\mathrm{OM} 2$ & 0.834 & & & & \\
\hline & OM3 & 0.881 & & & & \\
\hline & OM5 & 0.801 & & & & \\
\hline \multirow{7}{*}{ Standard operating procedure } & SOP1 & 0.906 & 0.732 & 0.95 & 0.939 & 0.94 \\
\hline & SOP2 & 0.860 & & & & \\
\hline & SOP3 & 0.826 & & & & \\
\hline & SOP4 & 0.853 & & & & \\
\hline & SOP5 & 0.854 & & & & \\
\hline & SOP7 & 0.840 & & & & \\
\hline & SOP8 & 0.847 & & & & \\
\hline \multirow{3}{*}{ Execution procedure } & MEP4 & 0.879 & 0.761 & 0.905 & 0.842 & 0.843 \\
\hline & MEP5 & 0.913 & & & & \\
\hline & MEP7 & 0.822 & & & & \\
\hline \multirow{2}{*}{ Backlog control } & BCPS4 & 0.937 & 0.893 & 0.943 & 0.88 & 0.891 \\
\hline & BCPS5 & 0.952 & & & & \\
\hline \multirow{6}{*}{ Maintenance policy } & MP10 & 0.868 & 0.76 & 0.95 & 0.937 & 0.939 \\
\hline & MP11 & 0.845 & & & & \\
\hline & MP2 & 0.850 & & & & \\
\hline & MP3 & 0.899 & & & & \\
\hline & MP4 & 0.878 & & & & \\
\hline & MP9 & 0.888 & & & & \\
\hline \multirow{3}{*}{ CMMS performance } & CMP1 & 0.842 & 0.806 & 0.925 & 0.878 & 0.882 \\
\hline & CMP2 & 0.937 & & & & \\
\hline & CMP3 & 0.911 & & & & \\
\hline \multirow{6}{*}{ Maintenance implementation } & Pr2 & 0.726 & 0.617 & 0.906 & 0.875 & 0.881 \\
\hline & $\operatorname{Pr} 3$ & 0.713 & & & & \\
\hline & $\operatorname{Pr} 5$ & 0.804 & & & & \\
\hline & Pr6 & 0.753 & & & & \\
\hline & $\operatorname{Pr} 7$ & 0.860 & & & & \\
\hline & Pr9 & 0.847 & & & & \\
\hline \multirow{2}{*}{ Personnel attitude } & PA2 & 0.973 & 0.945 & 0.972 & 0.942 & 0.943 \\
\hline & PA3 & 0.971 & & & & \\
\hline \multirow{2}{*}{ Maintenance review } & Per4 & 0.916 & 0.883 & 0.938 & 0.873 & 0.977 \\
\hline & Per6 & 0.963 & & & & \\
\hline
\end{tabular}

hypotheses to satisfy the study aim. The null hypothesis $H_{0}$ is evaluated against the alternative hypothesis $H_{1}$ :

$\mathrm{H}_{0}$ : there is no significant impact of personnel attitude on the performance of CMMS implementation for maintenance management in high-rise office buildings in Nigeria

$H_{1}$ : there is a significant impact of personnel attitude on the performance of CMMS implementation for maintenance management in high-rise office buildings in Nigeria

\section{Results}

4.1. Characteristics of Buildings. The popularity of high-rise buildings ranges between 7 and 10 floors, accounting for
$77.6 \%$, followed by 11-15 floors having 14.9\%. Meanwhile, buildings within 16-20 floors represent $4.5 \%$. Only $3 \%$ of the high-rise buildings were above 20 floors. Lagos State is separated into mainland and islands having quite a few differences in cost value and characteristics. Mainland accounted for $55.2 \%$ of the buildings, while islands accounted for $44.8 \%$. Ownership varies from public to private and jointly owned (public-private partnership, PPP), which were all exhibited. $77.6 \%$ of the buildings were privately owned, $19.4 \%$ were publicly owned, and $14.9 \%$ were jointly owned. This suggests that most high-rise office buildings are corporate buildings and are utilised by the private sector. Based on the survey data obtained, $43.3 \%$ were constructed in the last five years, $19.4 \%$ were between 6 and 10 years, $14.9 \%$ were above 20 years, and $12 \%$ were between 11 and 15 years. The survey clearly showed that the development of high-rise buildings 


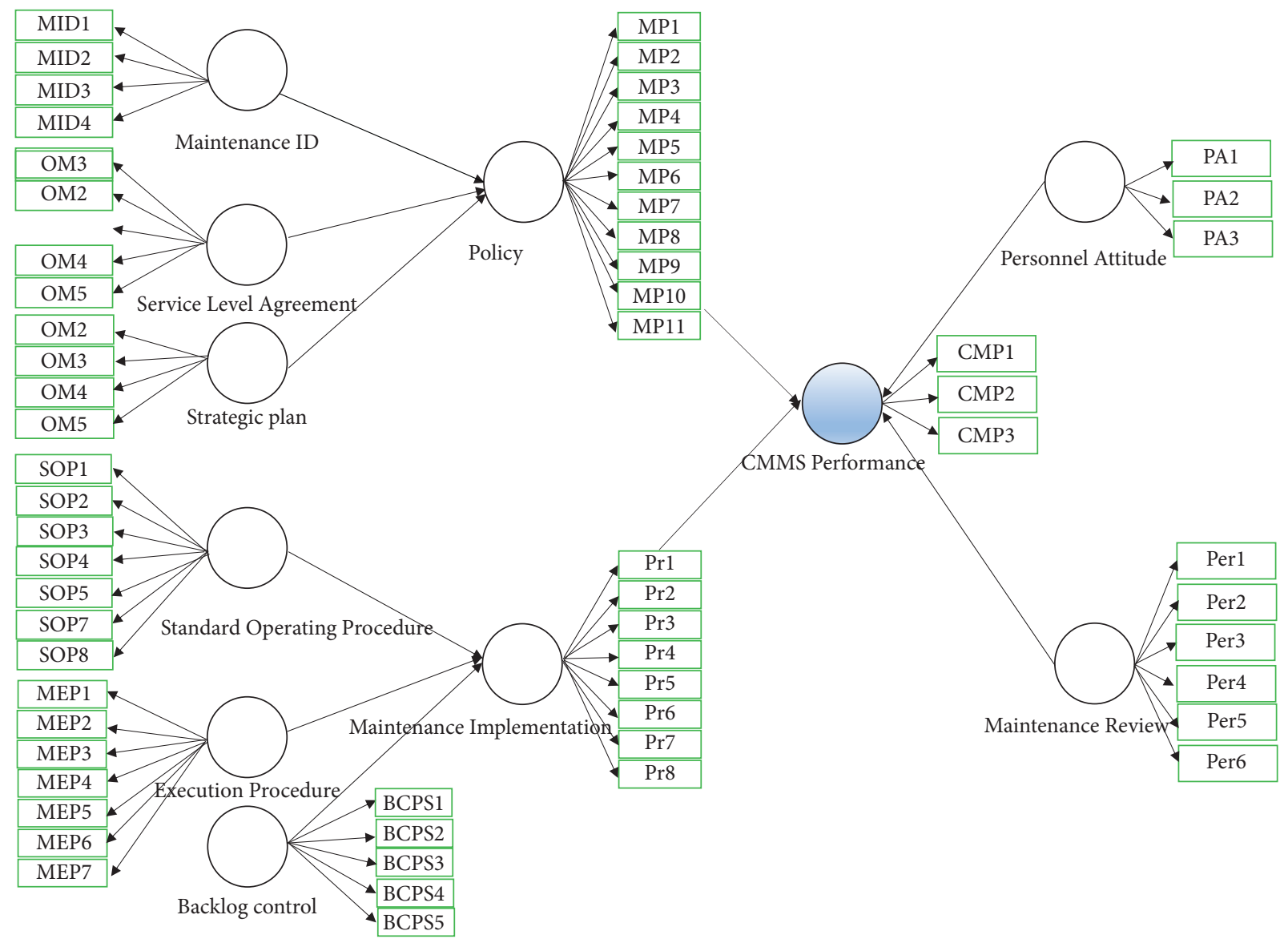

Figure 2: Hypothetical model.

resumed back within the last 15 years, accounting for $50 \%$ of high-rise offices presented in Figure 4.

4.2. Measurement Model for Performance of CMMS. When assessing a measurement model, the causal model direction is either reflective or formative. The status of the models is identified by the direction of arrows. When the arrow moves from construct to indicator, it is considered a reflective model, and when the arrow moves from indicator to construct, it represents a formative model. Reflective models are assessed based on their internal consistency, reliability, and validity, which include composite reliability, discriminant, and convergent validity [138]. The variables in this study constitute a reflective model; an algorithm was run to generate Average Variance Extracted (AVE), and other necessary reliability measurements to obtain the goodness of fit are presented in Table 2. For further confirmation of results from this study, Important Performance Map Analysis (IPMA) was conducted as posited in [149]. The IPMA in PLS-SEM broadens the strength of the results of the estimated path coefficient by taking the performance of each construct into consideration. Thus, conclusions can be drawn either by importance or by performance. The form of standard analysis on PLS-SEM will provide evidence on the relative importance of constructs in supporting other constructs in the model for the purpose of drawing conclusions as presented in Figure 5.
Accordingly, when assessing a reflective model, Hair et al. [150] noted that the indicator loadings exceeding 0.70 explained above $50 \%$ of the indicator variance. After the PLS-SEM algorithm was run, indicator items below 0.50 were removed (MID1, STD1, OM4, SOP6, MEP1, MEP2, MEP3, MEP6, BCPS1, BCPS2, BCPS3, MP1, MP5, MP6, MP7, MP8, Pr1, Pr4, Pr8, PA1, Per1, Per2, Per3, and Per5). Hence, the following cutoff points $\mathrm{a}, \mathrm{b}, \mathrm{c}$, and $\mathrm{d}$ were considered in this study:

(a) All item loading $>0.5$ indicates indicator reliability [151]

(b) All Average Variance Extracted (AVE) $>0.5$ indicates convergent reliability $[152,153]$

(c) All composite reliability $(\mathrm{CR})>0.7$ indicates internal consistency [154]

(d) All Cronbach alpha $(\mathrm{CA})>0.7$ indicates indicator reliability [155]

(e) Rho_ $A>0.7$ indicates additional supports on indicator reliability [138]

4.3. Predicted Effect of CMMS Performance. Three types of effects were considered: the direct effects of personnel attitude towards CMMS performance, the indirect effects of personnel attitude towards CMMS performance by having an intervening construct such as process implementation, SOP, and policy implementation in the organisation, and the 


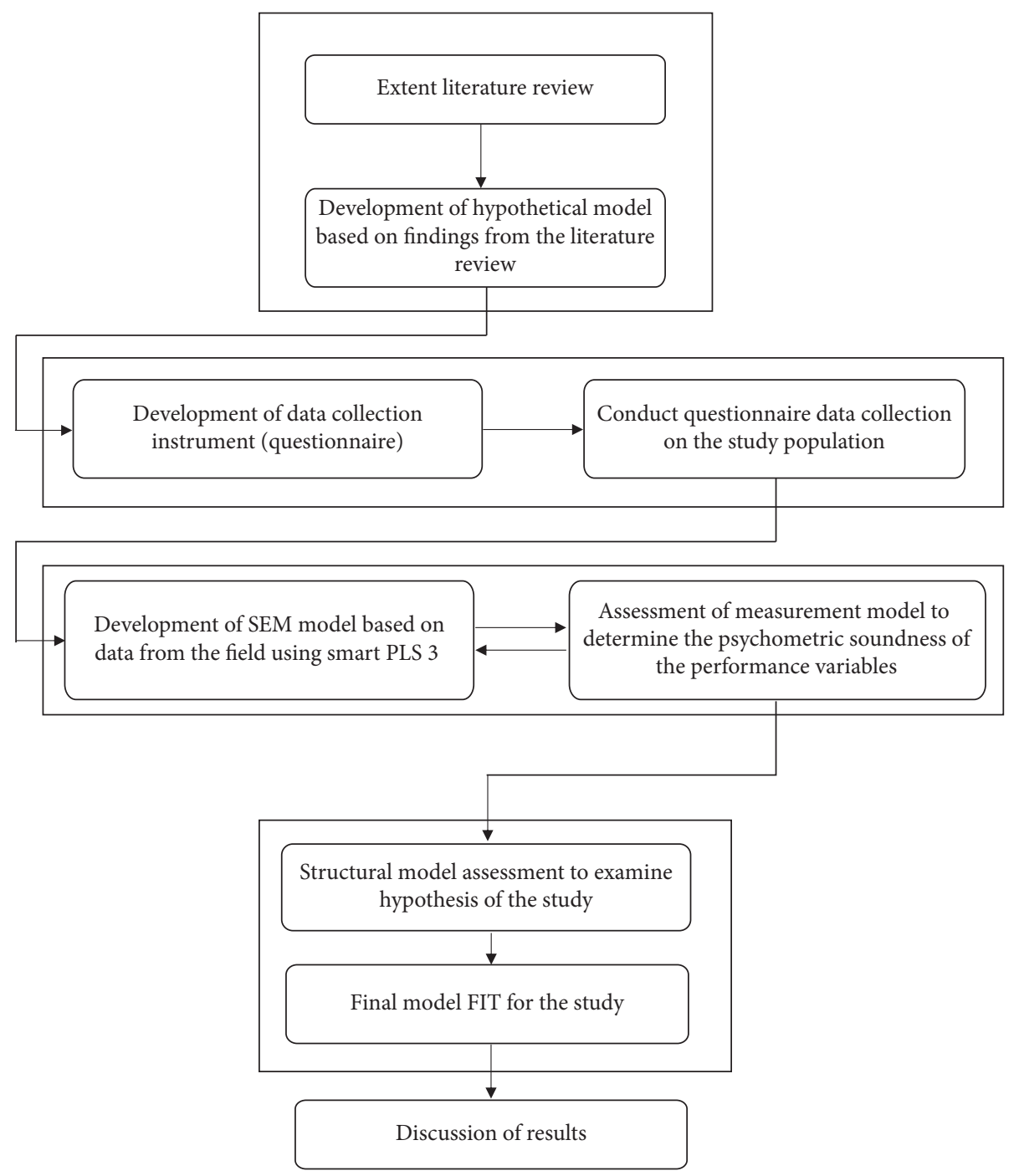

FIGURE 3: Research process.

total effects of all direct and indirect effects linked to CMMS performance. Therefore, their significance was assessed by means of bootstrapping. In Chin [156], bootstrapping estimates the spread, bias, and shape of the sample distribution of the population under examination. It creates a large prespecified number of samples, and every time sampling happens in bootstrap, the same number of cases as the original samples will be analysed.

\section{Discussion}

According to the result, personnel attitude shows a strong hold among maintenance execution procedure, policy review, SOP, and maintenance identification, thereby increasing maintenance performance. In essence, it shows that the maintenance performance of the organisation is indirectly influenced by personnel attitude. This supports the findings by Aduwo et al. [159] who found that an organisation will improve in productivity when a significant percentage of cost is invested in the aspect of personnel. Evidently, personnel attitude shows over 50\% contribution to individual components in the model, which can improve the performance of the organisation. Next is the outsourced maintenance tasks (SLA). The importance-performance map (Figure 5) shows the critical importance contribution of outsourced maintenance activities to the total effects. This explains the process to facilitate performance by the organisation as noted in the study by Mohamed et al. [39] that organisations rely mostly on outsourcing the key maintenance task and any failure will significantly affect the performance of the organisation. Furthermore, the difficulties of an organisation to oversee the entire support activities may be challenging, particularly when the organisations are thriving and with great competitors [160]. When the absolute values were highlighted (Figure 6), it was obvious that the position of personnel attitude remains a critical point of consideration; in this case, this situation supports Adenuga [161] who found disparities in outsourcing of maintenance tasks and execution using in-house labour. Maintenance departments are required to implement a sound policy to provide an appropriate basis for budget preparation to meet the actual maintenance needs of the organisation. This 


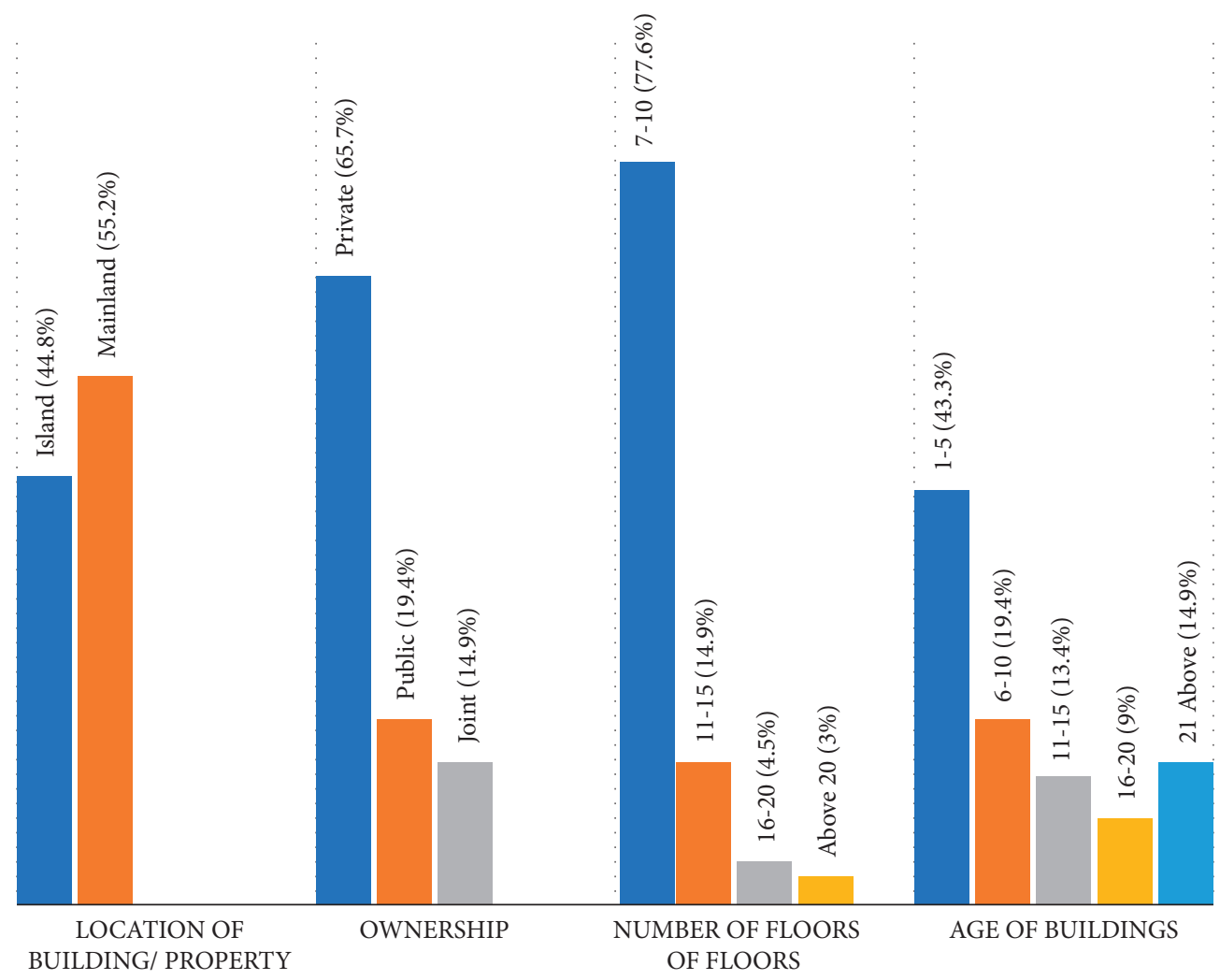

FIgURE 4: Characteristics of buildings.

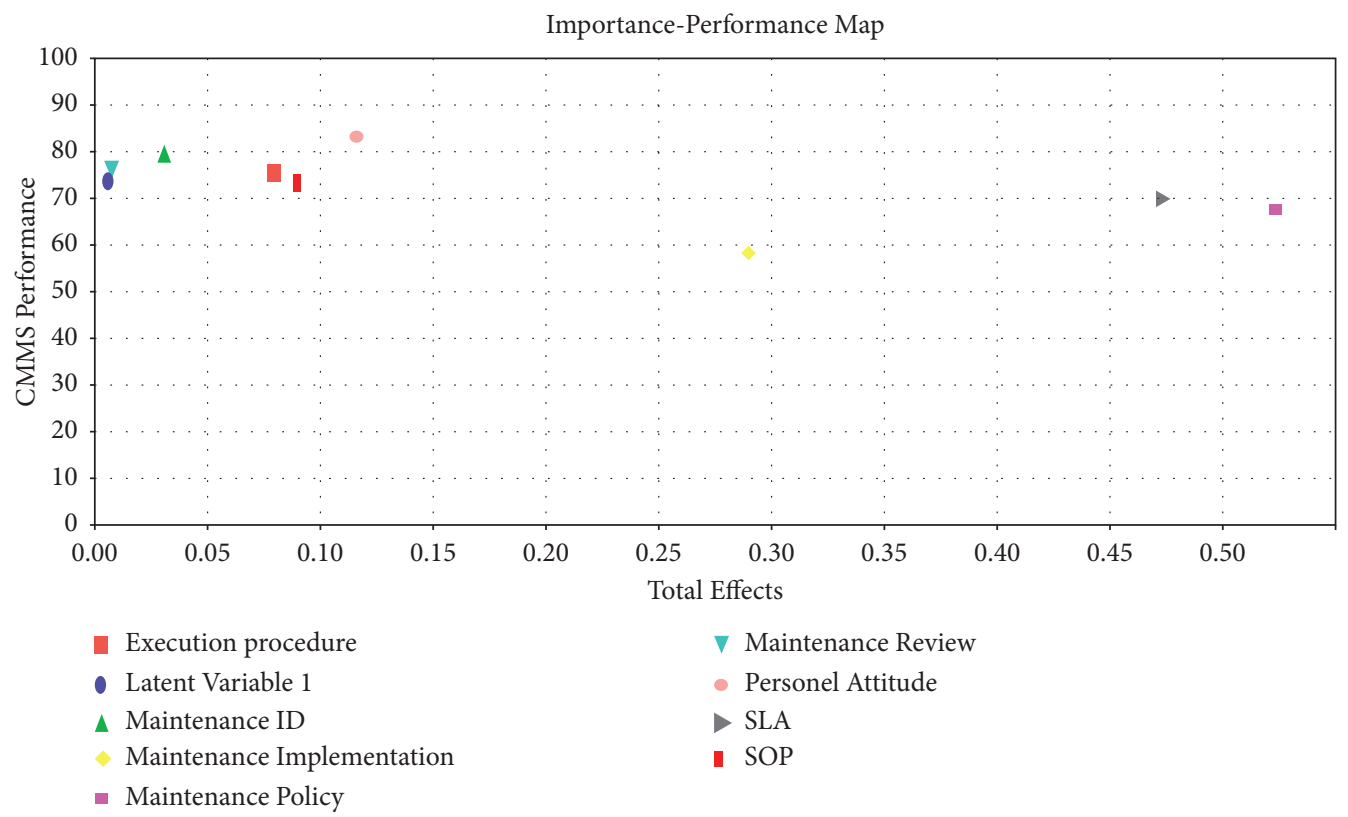

FIGURE 5: Importance-performance map construct standardised effects.

means that handling maintenance operations/activities would be very effective if the aspect of personnel attitude is included in the framework of the organisation.

The direct relationship between CMMS performance and personnel attitude presented in Table 3 shows no significant impact at $t$-value $=1.296$ and $P$ value $=0.155$. This could lead to an acceptance of the null hypothesis that states that there is no significant impact of personnel attitude on maintenance performance in CMMS deployment. Predictive relevance $q^{2}$ (Table 3) shows that personnel attitude significantly impacts 


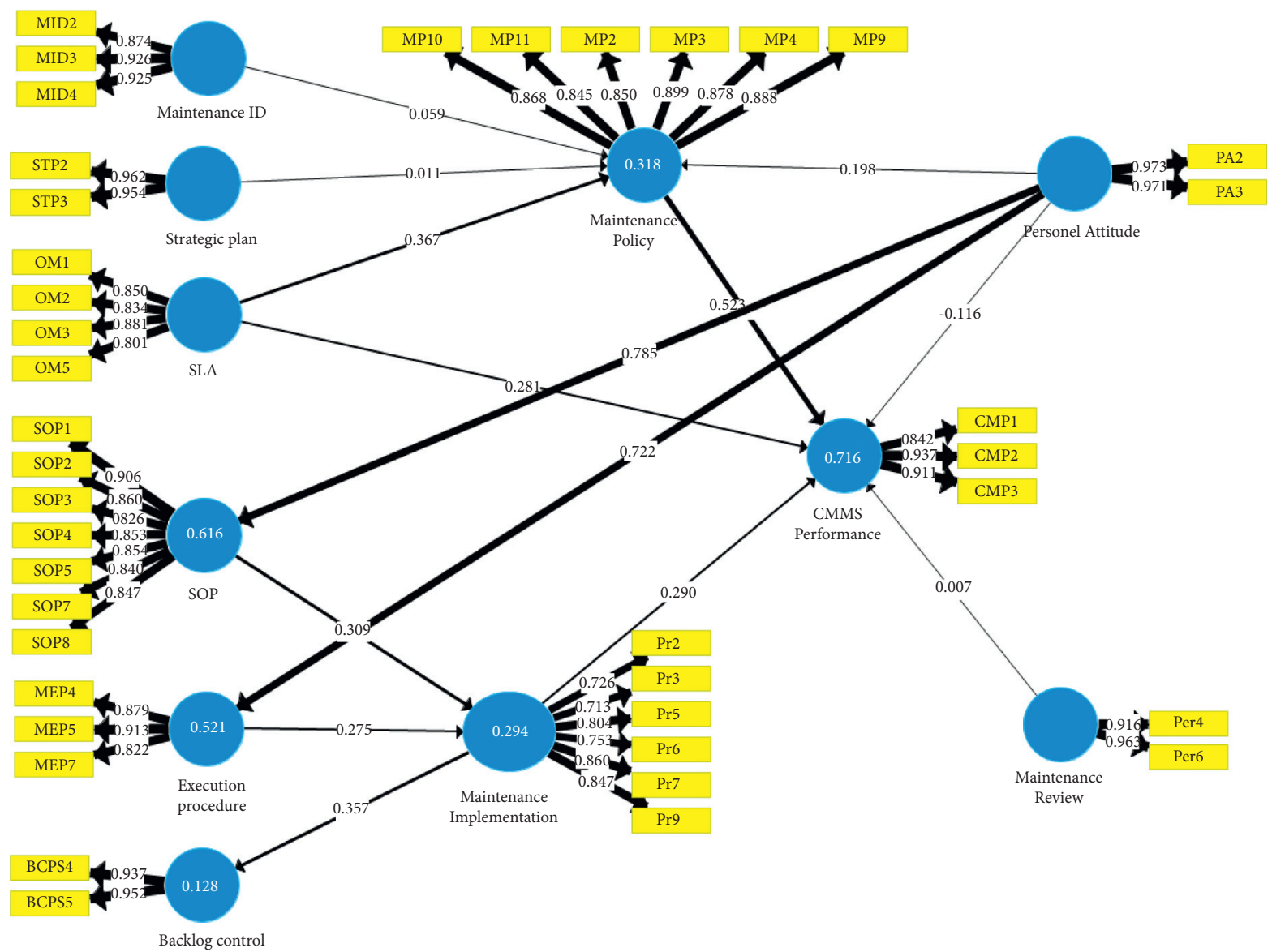

FIGURE 6: $R^{2}$ absolute values of CMMS performance model.

TABLE 3: Direct relationship for hypothesis testing.

\begin{tabular}{|c|c|c|c|c|c|c|c|c|c|c|}
\hline Hypothesis & Relationship & Std. beta & Std. error & $t$-value & Decision & $f^{2}$ & $q^{2}$ & $P$ value & $\begin{array}{l}5 \% \mathrm{CI} \\
\mathrm{UL}\end{array}$ & $\begin{array}{l}95 \% \text { CI } \\
\text { UL }\end{array}$ \\
\hline $\mathrm{H} 1$ & $\begin{array}{c}\text { Execution procedure - } \\
>\text { maintenance implementation }\end{array}$ & 0.286 & 0.103 & $2.659^{* *}$ & Supported & 0.050 & 0.025 & 0.008 & 0.038 & 0.555 \\
\hline $\mathrm{H} 2$ & $\begin{array}{l}\text { Maintenance ID -> maintenance } \\
\text { policy }\end{array}$ & 0.066 & 0.110 & 0.533 & $\begin{array}{c}\text { Not } \\
\text { supported }\end{array}$ & 0.001 & 0.000 & 0.594 & -0.224 & 0.357 \\
\hline $\mathrm{H} 3$ & $\begin{array}{c}\text { Maintenance implementation - } \\
>\text { backlog control }\end{array}$ & 0.367 & 0.074 & $4835^{* *}$ & Supported & 0.279 & 0.125 & 0.000 & 0.174 & 0.549 \\
\hline $\mathrm{H} 4$ & $\begin{array}{l}\text { Maintenance implementation - } \\
\text { > CMMS performance }\end{array}$ & 0.301 & 0.103 & $2.826 * *$ & Supported & 2.521 & 1.309 & 0.005 & 0.042 & 0.557 \\
\hline $\mathrm{H} 5$ & $\begin{array}{c}\text { Maintenance policy -> CMMS } \\
\text { performance }\end{array}$ & 0.509 & 0.100 & $5.220^{* *}$ & Supported & 2.521 & 1.309 & 0.000 & 0.216 & 0.712 \\
\hline H6 & $\begin{array}{c}\text { Maintenance review -> CMMS } \\
\text { performance }\end{array}$ & 0.018 & 0.065 & 0.116 & $\begin{array}{c}\text { Not } \\
\text { supported }\end{array}$ & 0.000 & 0.000 & 0.908 & -0.164 & 0.193 \\
\hline $\mathrm{H} 7$ & $\begin{array}{c}\text { Personnel attitude -> CMMS } \\
\text { performance }\end{array}$ & -0.106 & 0.089 & 1.296 & $\begin{array}{l}\text { Not } \\
\text { supported }\end{array}$ & 0.018 & 0.007 & 0.195 & -0.319 & 0.141 \\
\hline $\mathrm{H} 8$ & $\begin{array}{c}\text { Personnel attitude -> execution } \\
\text { procedure }\end{array}$ & 0.720 & 0.057 & $12.59^{* *}$ & Supported & 1.088 & 0.623 & 0.000 & 0.548 & 0.838 \\
\hline $\mathrm{H} 9$ & $\begin{array}{c}\text { Personnel attitude }->\text { maintenance } \\
\text { policy }\end{array}$ & 0.200 & 0.130 & 1.524 & $\begin{array}{c}\text { Not } \\
\text { supported }\end{array}$ & 0.025 & 0.017 & 0.128 & -0.124 & 0.562 \\
\hline $\mathrm{H} 1$ & Personnel attitude $->$ SOP & & & 2 & Supported & 1.604 & & & 0.693 & .852 \\
\hline $\mathrm{H} 11$ & SLA $->$ CMMS $p$ & & & & & 0.1 & & & 0.054 & 0.451 \\
\hline $\mathrm{H} 12$ & SLA $->$ maintenance policy & 0.369 & 0.130 & $2.818^{* *}$ & Supported & 0.091 & 0.059 & 0.005 & 0.06 & 0.704 \\
\hline $\mathrm{H} 13$ & $\begin{array}{l}\text { SOP }->\text { maintenance } \\
\text { implementation }\end{array}$ & 0.304 & 0.111 & $2.777^{* *}$ & Supported & 0.067 & 0.030 & 0.006 & -0.003 & 0.569 \\
\hline H14 & $\begin{array}{l}\text { Strategic plan }->\text { maintenance } \\
\text { policy }\end{array}$ & 0.000 & 0.098 & 0.112 & $\begin{array}{c}\text { Not } \\
\text { supported }\end{array}$ & 0.000 & 0.000 & 0.911 & -0.293 & 0.213 \\
\hline
\end{tabular}

Author's compilation: ${ }^{* *} P<0.01,{ }^{*} P<0.05$. (i) Effect size and impact indicators are according to Cohen [157]; $f^{2}$ values: 0.35 (large), 0.15 (medium), and 0.02 (small). (ii) $q^{2}$ predictive relevance $\left(Q^{2}\right)$ of predictor exogenous latent variables as according to Henseler et al. [158]; $q^{2}$ values: 0.35 (large), 0.15 (medium), and 0.02 (small). 
TABle 4: Specific indirect effects for hypothesis testing.

\begin{tabular}{|c|c|c|c|c|c|c|c|}
\hline & $\begin{array}{l}\text { Original sample } \\
(\mathrm{O})\end{array}$ & $\begin{array}{c}\text { Sample } \\
\text { mean }(\mathrm{M})\end{array}$ & $\begin{array}{l}\text { Standard } \\
\text { deviation } \\
(\text { STDEV) }\end{array}$ & $\begin{array}{l}\text { T statistics } \\
\quad(\mid \mathrm{O} / \\
\text { STDEV } \mid)\end{array}$ & $\begin{array}{c}P \\
\text { values }\end{array}$ & $0.50 \%$ & $99.50 \%$ \\
\hline $\begin{array}{l}\text { Execution procedure -> maintenance } \\
\text { implementation }->\text { backlog control }\end{array}$ & 0.098 & 0.104 & 0.044 & 2.248 & 0.025 & 0.007 & 0.223 \\
\hline $\begin{array}{l}\text { Personnel attitude }->\text { execution procedure - } \\
>\text { maintenance implementation }->\text { backlog } \\
\text { control }\end{array}$ & 0.071 & 0.075 & 0.033 & 2.124 & 0.034 & 0.006 & 0.168 \\
\hline $\begin{array}{l}\text { SOP -> maintenance implementation - } \\
>\text { backlog control }\end{array}$ & 0.110 & 0.114 & 0.054 & 2.060 & 0.040 & -0.002 & 0.284 \\
\hline $\begin{array}{l}\text { Personnel attitude }->\text { SOP }->\text { maintenance } \\
\text { implementation }->\text { backlog control }\end{array}$ & 0.087 & 0.090 & 0.043 & 2.006 & 0.045 & -0.002 & 0.234 \\
\hline $\begin{array}{l}\text { Execution procedure }->\text { maintenance } \\
\text { implementation }->\text { CMMS performance }\end{array}$ & 0.080 & 0.085 & 0.042 & 1.897 & 0.058 & 0.010 & 0.234 \\
\hline $\begin{array}{l}\text { Personnel attitude }->\text { execution procedure - } \\
>\text { maintenance implementation }->\text { CMMS } \\
\text { performance }\end{array}$ & 0.058 & 0.061 & 0.031 & 1.867 & 0.062 & 0.008 & 0.177 \\
\hline $\begin{array}{l}\text { SOP }->\text { maintenance implementation }->\text { CMMS } \\
\text { performance }\end{array}$ & 0.090 & 0.090 & 0.044 & 2.049 & 0.041 & 0.006 & 0.231 \\
\hline $\begin{array}{l}\text { Personnel attitude }->\text { SOP }->\text { maintenance } \\
\text { implementation }->\text { CMMS performance }\end{array}$ & 0.070 & 0.071 & 0.035 & 2.024 & 0.043 & -0.001 & 0.189 \\
\hline $\begin{array}{l}\text { Maintenance ID -> maintenance policy - } \\
\text { > CMMS performance }\end{array}$ & 0.032 & 0.032 & 0.057 & 0.559 & 0.577 & -0.133 & 0.197 \\
\hline $\begin{array}{l}\text { Personnel attitude }->\text { maintenance policy - } \\
>\text { CMMS performance }\end{array}$ & 0.105 & 0.095 & 0.062 & 1.681 & 0.093 & -0.068 & 0.298 \\
\hline $\begin{array}{l}\text { SLA -> maintenance policy -> CMMS } \\
\text { performance }\end{array}$ & 0.194 & 0.198 & 0.083 & 2.331 & 0.020 & 0.012 & 0.417 \\
\hline $\begin{array}{l}\text { Personnel attitude }->\text { execution procedure - } \\
>\text { maintenance implementation }\end{array}$ & 0.199 & 0.205 & 0.078 & 2.553 & 0.011 & 0.026 & 0.432 \\
\hline $\begin{array}{l}\text { Personnel attitude -> SOP -> maintenance } \\
\text { implementation }\end{array}$ & 0.243 & 0.240 & 0.089 & 2.713 & 0.007 & -0.005 & 0.459 \\
\hline
\end{tabular}

Authors' compilation.

maintenance execution procedure having a large effect size and predictive relevance $\left(t\right.$-value $\left.=12.59 ; q^{2}=0.623\right)$ and SOP with $\left(t\right.$-value $\left.=25.646 ; q^{2}=0.802\right)$. With the bootstrapping analysis as previously explained, it shows that personnel attitude has an indirectly significant effect on CMMS performance. Table 4 shows an indirect significance to CMMS performance through execution procedure $(t$-value $=1.867 ; P$ value $=0.062)$, Maintenance Implementation and SOP $(t$-value $=2.024 ; P$ value $=0.043)$, and policy $(t$-value $=1.681 ; P$ value $=0.093)$. The importance-performance map (Figure 5) shows the position of personnel attitude having a strong hold among maintenance execution procedure, policy review, SOP, and maintenance identification, thereby increasing maintenance performance. This translates to the fact that personnel attitude is significantly related to CMMS performance as expressed in the alternative hypothesis $H_{1}$ that is hereby accepted.

\section{Conclusion and Directions for Further Studies}

This study aimed to explore and predict elements towards improving the maintenance performance of high-rise office buildings in Lagos, Nigeria. The study established that the mere presence of performance measurement does not guarantee automatic efficiency. Thus, the significance of human efforts is indispensable even with CMMS. The results noted an indirect strong effect size and predictive relevance of personnel attitudes and a significant need to have a functional framework that measures their attitudes and to provide financial priority to maintenance management while investing in new technologies to improve. The current performance of outsourced operations strives better even though the strategies can be improved. The established performance dimensions are strongly connected and influence the mental state (attitude) of the personnel.

6.1. Theoretical and Practical Implications of the Study. The empirical analysis in this study has established the place of personnel attitude in performance elements that should be improved for effective maintenance of high-rise office buildings. The study tested new performance variables by adopting literature from telecommunications and marketing research with evidence to highlight their improvements in performance. Theoretically, this study suggests that the strategic role of management determines the service quality while promoting budget allocation, innovation, and personnel training and improving other operational measures. On the other hand, in real-life situations, the established model can promote awareness of new aspects of performance measures that may be integrated into high-rise maintenance strategies. However, this requires management 
to adopt and incorporate framework components from telecommunications and marketing organisations in utilisation performance data systematically to improve an effective maintenance service delivery cycle. Because there are few studies that have examined the place of personnel attitude, and because the problem of high-rise office maintenance management is common among developing countries, maintenance practitioners should invest in personnel as more as they invest in clients. Meanwhile, the structural model can be adapted elsewhere with ease based on its generic nature.

6.2. Limitations and Suggestions for Further Study. The technicality of strategic FM is an emerging sector in Nigeria and other countries in sub-Sahara Africa. It is not unexpected that the abundance of scientific information may be deficient. To an extent, the indicators in this study were generic and even cut across the marketing research fields. The sample size was considered moderate. Although, the model met all criteria for statistical fitness. Performance scores utilised for analysis were built on respondents' perception, which certainly carries the value judgments of respondents. Other moderating indicators which could influence the model may also be considered in future studies.

\section{Data Availability}

The study utilised both primary and secondary data. The study began with the extraction of variables from published frameworks after critical literature of literature and analysed which forms the performance variable in the survey questionnaire. The questionnaire administration was conducted among respondents within the FM organisation in Lagos State, Nigeria. However, not all respondents were involved in high-rise office FM. Thus, in the questionnaire, two conditions were set (types of building and number of floors) to discontinue respondents who were not qualified. A total number of 134 responses were received and analysed for this study. These were personnel directly or indirectly connected to the maintenance management operations of the high-rise buildings. The data from the survey were analysed using Statistical Package for Social Sciences (SPSS) for the first phase of descriptive analysis, and PLS-SEM using SMART PLS 3 was used in the second phase as presented in the study.

\section{Conflicts of Interest}

The authors declare that they have no conflicts of interest.

\section{References}

[1] A. Elmualim, R. Valle, and W. Kwawu, "Discerning policy and drivers for sustainable facilities management practice," International Journal of Sustainable Built Environment, vol. 1, no. 1, pp. 16-25, 2012.

[2] S. Lavy, J. A. Garcia, and M. K. Dixit, "Establishment of KPIs for facility performance measurement: review of literature," Facilities, vol. 28, no. 9/10, 2010a.
[3] S. Lavy, J. A. Garcia, and M. K. Dixit, "Establishment of KPIs for facility performance measurement: review of literature," Facilities, vol. 28, no. 9/10, pp. 440-464, 2010 b.

[4] E. M. A. Zawawi and S. N. Kamaruzzaman, "Personnel characteristics of maintenance practice: a case of high-rise office buildings in Malaysia," Journal of Sustainable Development, vol. 2, no. 1, pp. 111-116, 2009.

[5] N. E. Myeda, S. N. Kamaruzzaman, and M. Pitt, "Measuring the performance of office buildings maintenance management in Malaysia," Journal of Facilities Management, vol. 9, no. 3, pp. 181-199, 2011.

[6] O. A. Lateef, "Building maintenance management in Malaysia," Journal of Building Appraisal, vol. 4, no. 3, pp. 207-214, 2009.

[7] F. W. Yik, W. L. Lee, and C. Ng, "Building energy efficiency and the remuneration of operation and maintenance personnel," Facilities, vol. 20, no. 13/14, pp. 406-413, 2002.

[8] M. T. Lakhiar, M. T. Lakhiar, M. T. Lakhiar, and A. H. Abdullah, "Occupational health and safety performance in high-rise building projects in Pakistan: a systematic literature review," Operational Research in Engineering Sciences: Theory and Applications, vol. 4, no. 1, pp. 99-114, 2021.

[9] J. H. Armstrong, Maintaining Building Services: A Guide for Managers, Mitchell, CA, USA, 1987.

[10] H. J. Balouei, J. P. Khazaei, S. M. S. Khaksar, S. M. Arabzad, and R. V. Kazemi, "Impacts of computerized maintenance management system and relevant supportive organizational factors on total productive maintenance," Benchmarking: An International Journal, vol. 25, no. 7, pp. 2230-2247, 2018.

[11] H. B. Jamkhaneh, J. K. Pool, S. M. S. Khaksar, S. M. Arabzad, and R. V. Kazemi, "Impacts of computerized maintenance management system and relevant supportive organizational factors on total productive maintenance," Benchmarking: An International Journal, vol. 25, no. 21, 2018.

[12] D. Mather, CMMS: A Timesaving Implementation Process, CRC Press, FL, USA, 2002.

[13] J. Laurila, Developing Computerized Maintenance Management System, Master Thesis, Metropolia, Metropolia, Finland, 2017.

[14] C. Eastman, P. Teicholz, R. Sacks, and K. Liston, BIM Handbook: A Guide to Building Information Modeling for Owners, Managers, Designers, Engineers and Contractors, John Wiley \& Sons, NJ, USA, 2011.

[15] M. Wienker, K. Henderson, and J. Volkerts, "The computerized maintenance management system an essential tool for world class maintenance," Procedia Engineering, vol. 138, pp. 413-420, 2016.

[16] D. Liptrot and G. Palarchio, "Utilizing advanced maintenance practices and information technology to achieve maximum equipment reliability," International Journal of Quality \& Reliability Management, vol. 17, no. 8, 2000a.

[17] D. Collins and A. Junghans, "Sustainable facilities management and green leasing: the company strategic approach," Procedia Economics and Finance, vol. 21, pp. 128-136, 2015.

[18] A. Ogbo, N. Eneh, C. Mbah, and D. Isijola, "Effects of computerised maintenance management systems on performance of selected manufacturing companies in Enugu state, Nigeria," Science and Technology, 2018.

[19] E. H. Klaber, "The skyscraper: boon or bane?" Journal of Land and Public Utility Economics, vol. 6, no. 4, pp. 354-358, 1930.

[20] S. Ayşin and A. Özgen, "Space efficiency in high-rise office buildings," Metu Jfa, vol. 2, 2009. 
[21] A. Wood, Best Tall Buildings 2008: CTBUH International Award Winning Projects, Elsevier, Amsterdam, Netherlands, 2008.

[22] National Fire Protection Association, "List of nfpa codes and standards," 2011, https://www.nfpa.org/standard_items/ search_results?searchStr=high-rise.

[23] A. A. Aliyu, H. A. Funtua, A. Mammadi, and B. G. Bukar, "Problems associated with elevators in high-rise commercial buildings in north-western state capitals of nigeria," Journal of Energy Technologies and Policy, vol. 5, 2015.

[24] S.-n. Kamaruzzaman, N. E. Myeda, and M. Pitt, "Performance levels of high-rise private office buildings maintenance management in Malaysia," Eksploatacja i Niezawodność, vol. 15, no. 2, pp. 111-116, 2013.

[25] S. W. Abd, A. Sairi, A. A. Che, N. M. Tawil, and S. Johar, "Building maintenance issues: a Malaysian scenario for high rise residential buildings," International Journal of Applied Engineering Research, vol. 10, no. 6, Article ID 15759, 2015.

[26] O. Amankwah, C. Weng-Wai, and A. H. Mohammed, "Modelling the mediating effect of health care healing environment on core health care delivery and patient satisfaction in Ghana," Environmental Health Insights, vol. 13, 2019.

[27] O. Faremi, O. Adenuga, and J. Ameh, "Maintenance management sourcing strategies and the condition of tertiary institution buildings in Lagos and Ogun States, Nigeria," Ethiopian Journal of Environmental Studies and Management, vol. 10, no. 1, pp. 64-74, 2017.

[28] O. Ajayi and O. Adenuga, Poor Maintenance Culture of Hospital Buildings in Lagos State, Nigeria, University of Lagos, Lagos, Nigeria, 2010.

[29] A. Salonen, "Strategic maintenance improvement: driving forces and obstacles," Engineering Asset Management and Infrastructure Sustainability, Springer, Berlin, Germany, pp. 789-800, 2012.

[30] A. O. Alejo, "The maintenance of tertiary institution buildings in ondo state, Nigeria: practice, problem and prospect," Civil and Environmental Research, vol. 10, no. 5, 2018.

[31] O. Blessing, J. Richard, and A. Emmanuel, “Assessment of building maintenance management practices of higher education institutions in Niger State-Nigeria," Journal of Design and Built Environment, vol. 15, no. 2, 2015.

[32] M. Olowoake, "A theoretical framework to support facilities maintenance management of higher education institutions buildings in Nigeria," $\mathrm{PhD}$ thesis, University of Salford, Salford, England, 2015, http://usir.salford.ac.uk/35209/.

[33] O. O. Ugwu, C. C. Okafor, and C. U. Nwoji, "Assessment of building maintenance in Nigerian university system: a case study of University of Nigeria, Nsukka," Nigerian Journal of Technology, vol. 37, no. 1, pp. 44-52, 2018.

[34] Y. A. Adetoro and O. A. Damilola, "Attitudes of Nigerian facilities management professionals to the benefits of benchmarking," Facilities, vol. 34, no. 7/8, pp. 468-492, 2016.

[35] A. M. Olufunke, "Education for maintenance culture in Nigeria: implications for community development," International Journal of Sociology and Anthropology, vol. 3, no. 8, pp. 290-294, 2011.

[36] H. Koleoso, M. Omirin, and Y. Adewunmi, "Comparison of the nature and strategic features of facilities management and other building support practices in Lagos," ATBU Journal of Environmental Technology, vol. 8, no. 2, pp. 11-29, 2015b.
[37] H. A. Koleoso, M. M. Omirin, and F. Adejumo, "Comparison of strategic content of facilities managers functions with other building support practitioners in Lagos, Nigeria," Property Management, vol. 36, no. 2, pp. 137-155, 2018.

[38] T. Åhrén and A. Parida, "Maintenance performance indicators (MPIs) for benchmarking the railway infrastructure," Benchmarking: An International Journal, vol. 16, no. 2, 2009.

[39] A. Mohamed, A. H. Mohammed, and M. N. Abdullah, "Service level agreements: governance in outsourcing facility management," Jurnal Teknologi, vol. 73, no. 5, 2015.

[40] N. Igbokwe and H. Godwin, "Maintenance performance evaluation and downtime analysis of manufacturing equipment in a food manufacturing company," Journal of Engineering Research and Reports, vol. 20, no. 11, 2021.

[41] A. Salonen and M. Deleryd, "Cost of poor maintenance: a concept for maintenance performance improvement," Journal of Quality in Maintenance Engineering, vol. 17, no. 1, 2011.

[42] J. M. Simões, C. F. Gomes, and M. M. Yasin, "A literature review of maintenance performance measurement: a conceptual framework and directions for future research," Journal of Quality in Maintenance Engineering, vol. 17, no. 2, 2011.

[43] B. Nutt and P. McLennan, Facility Management Risks and Opportunities, Wiley-Blackwell, NJ, USA, 2001.

[44] R. S. Kaplan and D. P. Norton, "The balanced scorecard: measures that drive performance," Harvard Business Review, vol. 83, no. 7, 2005.

[45] A. Parida and U. Kumar, "Maintenance performance measurement (MPM): issues and challenges," Journal of Quality in Maintenance Engineering, vol. 12, no. 3, 2006.

[46] M. Asiedu, J. O. Sarfo, J. O. Sarfo, D. Adjei, N. Asiedu, and H. Adusei, "Model of customer service, belongingness and satisfaction: a multidisciplinary analysis of needs in Ghanaian banking sector," European Journal of Economic Studies, vol. 8, no. 2, pp. 52-61, 2014.

[47] A. M. Ghalayini, J. S. Noble, and T. J. Crowe, "An integrated dynamic performance measurement system for improving manufacturing competitiveness," International Journal of Production Economics, vol. 48, no. 3, pp. 207-225, 1997.

[48] K. B. Rahadi, A. Setyanto, and D. Rohmansyah, "Application of theory of constraints (TOC) in power generation to increase overhaul maintenance performance and to strengthen overhaul management process," IOP Conference Series: Materials Science and Engineering, vol. 1096, no. 1, Article ID 012130, 2021.

[49] A. A. Atkinson, J. H. Waterhouse, and R. B. Wells, "A stakeholder approach to strategic performance measurement," MIT Sloan Management Review, vol. 38, no. 3, p. 25, 1997.

[50] T. Wireman, Developing Performance Indicators for Managing Maintenance, Industrial. Press, New York, NY, USA, 1998.

[51] M. N. Wahed and R. Kibria, "A comprehensive study on smart city compatibility of divisional cities in Bangladesh," International Journal of Engineering and Technical Research (IJETR), vol. 5, no. 2, pp. 159-164, 2016.

[52] D. Amaratunga, D. Baldry, and M. Sarshar, "Assessment of facilities management performance - what next?" Facilities, vol. 18 , no. $1 / 2$, pp. $66-75,2000$.

[53] L. Gouws and J. Trevelyan, Research on Influences on Maintenance Management Effectiveness Engineering Asset Management, pp. 72-79, Springer, Berlin, Germany, 2006. 
[54] P. G. Taylor, P. Upham, W. McDowall, and D. Christopherson, "Energy model, boundary object and societal lens: 35 years of the MARKAL model in the UK," Energy Research \& Social Science, vol. 4, pp. 32-41, 2014.

[55] A. A. Afonja, K. L. Sraku, and A. Oni, Engineering Education for Industrial Training, Development. Case Study of Nigeria, Ghana and Zimbabwe, 2005.

[56] M. H. M. Faris, E. Elhussein, H. Osman, and A. Yousif, "Enhance and Develop the Key Performance Indicators for Large Maintenance Sectors," International Research Journal of Advanced Engineering and Science, vol. 6, no. 1, 2021.

[57] A. C. Márquez, "Maintenance management characterization: process, framework and supporting pillars," The Maintenance Management Framework: Models and Methods for Complex Systems Maintenance, pp. 11-40, Springer, Berlin, Germany, 2007.

[58] Queensland Government, Maintenance Management Framework Policy for the Maintenance of Queensland Government BuildingsDepartment of Housing and Public Works, Queensland, Australia, 2017, https://www.hpw.qld. gov.au/_data/assets/pdf_file/0018/3276/mmf.pdf.

[59] A. Raveenthiran, "Human dimensions in integrated asset management," Engineering Asset Management and Infrastructure Sustainability, pp. 759-777, Springer, London, 2012.

[60] H. H. Y. Lee and D. Scott, "Overview of maintenance strategy, acceptable maintenance standard and resources from a building maintenance operation perspective," Journal of Building Appraisal, vol. 4, no. 4, pp. 269-278, 2009.

[61] M. R. Yahya and M. N. Ibrahim, "Building maintenance policy for office buildings in Malaysia: a prelimnary study in klang valley," in Proceedings of the the $2 \mathrm{Nd}$ International Conference on Public Policy \& Social Sicences 2011 (ICoPS 2011), pp. 1-6, Kuala Lumpur, Malasiya, May 2011.

[62] S. Fore and L. Zuze, "Improvement of overall equipment effectiveness through total productive maintenance," World Academy of Science, Engineering and Technology, vol. 61, no. 1, 2010.

[63] G. Pinto, F. J. G. Silva, A. Baptista, N. O. Fernandes, R. Casais, and C. Carvalho, "TPM implementation and maintenance strategic plan - a case study," Procedia Manufacturing, vol. 51, pp. 1423-1430, 2020.

[64] M. A. Koussaimi, D. Bouami, and S. Elfezazi, "Improvement maintenance implementation based on downtime analysis approach," Journal of Quality in Maintenance Engineering, vol. 22, no. 4, 2016.

[65] T. K. Baaki, M. R. Baharum, and A. S. Ali, "Determining a conceptual framework for safe and sustainable health-care waste management (SSHCWM) implementation in healthcare facilities," Journal of Facilities Management, vol. 17, no. 1, 2019.

[66] M. A. Hassanain, F. Fatayer, and A. M. Al-Hammad, "Design-phase maintenance checklist for electrical systems," Journal of Performance of Constructed Facilities, vol. 30, no. 2, Article ID 06015003, 2016.

[67] S. Liaqat, A. Fatima, M. Riaz, and A. Rehman, "Assessment and development of framework of building maintenance management practices in construction industry of Pakistan," in Proceedings of the 2nd International Conference on Sustainable Development in Civil Engineering, MUET, Jamshoro, Pakistan, December 2019.

[68] A. L. Olanrewaju and A. R. A. Abdul, "Building maintenance processes, principles, procedures, practices and strategies," in Building Maintenance Processes and Practices, pp. 79-129, Springer, Singapore, 2015.

[69] R. M. W. Horner, M. El-Haram, and A. Munns, "Building maintenance strategy: a new management approach," Journal of Quality in Maintenance Engineering, vol. 3, no. 4, 1997.

[70] C. Lundgren, J. Bokrantz, and A. Skoogh, "A strategy development process for Smart Maintenance implementation," Journal of Manufacturing Technology Management, vol. 32, no. 9, 2021

[71] V. Libal, M. Raymond, L. M. Kiff, and H. Chen, Providing a Standard Operating Procedure Associated with a Monitoring System of a Facility: Google Patents 10,795,348 B2, 2017.

[72] S. Abdullah, S. Zubedy, and N. U. M. Najib, "Residents' maintenance priorities preference: the case of public housing in Malaysia," Procedia-Social and Behavioral Sciences, vol. 62, pp. 508-513, 2012.

[73] M. Sharp and K. Jones, "Perceived inefficiency in social housing maintenance," Construction Innovation, vol. 12, no. 4, 2012.

[74] D. Mike, "Maintenance backlog: take control with a priority index," 2020, https://www.prometheusgroup.com/posts/ maintenance-backlog-take-control-with-a-priority-index.

[75] D. Stokic, S. Scholze, and J. Barata, "Self-learning embedded services for integration of complex, flexible production systems," in Proceedings of the IECON 2011-37th Annual Conference of the IEEE Industrial Electronics Society, pp. 415-420, Melbourne, VIC, Australia, November 2011.

[76] F. Syafar and J. Gao, "Mobile collaboration technology in engineering asset maintenance: a Delphi study," in Proceedings of the Proceedings of the 2013 IEEE 17th International Conference on Computer Supported Cooperative Work in Design (CSCWD), pp. 483-488, Whistler, BC, Canada, June 2013.

[77] P. Giannozzi, O. Andreussi, T. Brumme et al., "Advanced capabilities for materials modelling with Quantum ESPRESSO," Journal of Physics: Condensed Matter, vol. 29, no. 46, Article ID 465901, 2017.

[78] H. Hammami, G. Calvary, M. Riahi, F. Moussa, and S. Bouzit, "Comparative Evaluation? Yes, but with Which Alternative Ui?" in Proceedings of the Electronic Visualisation And the Arts (EVA 2017), pp. 1-7, London, England, July 2017.

[79] T. T. D. T. Nguyen, T. Garncarz, F. Ng, L. A. Dabbish, and S. P. Dow, "Fruitful Feedback: positive affective language and source anonymity improve critique reception and work outcomes," in Proceedings of the Proceedings of the 2017 ACM Conference on Computer Supported Cooperative Work and Social Computing, pp. 1024-1034, Portland, Oregon, February 2017.

[80] U. Wemmerlöv, "A taxonomy for service processes and its implications for system design," International Journal of Service Industry Management, vol. 1, no. 3, 1990.

[81] G. M. Campbell, "Cross-utilization of workers whose capabilities differ," Management Science, vol. 45, no. 5, pp. 722-732, 1999.

[82] M. J. Brusco and T. R. Johns, "A sequential integer programming method for discontinuous labor tour scheduling," European Journal of Operational Research, vol. 95, no. 3, pp. 537-548, 1996.

[83] R. C. Burleson, C. T. Haas, R. L. Tucker, and A. Stanley, "Multiskilled labor utilization strategies in construction," Journal of Construction Engineering and Management, vol. 124, no. 6, pp. 480-489, 1998. 
[84] J. C. Stanley, "The changing vascular surgery workforce," Proceedings of the Seminars in Vascular Surgery, vol. 10, no. 2, pp. 65-71, 1997.

[85] NextTechnik, "Mean Time between Failures (MTBF): How to Calculate and Increase it," 2020, https://nextservicesoftware. $\mathrm{com} /$ news/mean-time-between-failures-mtbf/.

[86] K. T. Patel and N. P. Chotai, "Documentation and records: harmonized GMP requirements," Journal of Young Pharmacists, vol. 3, no. 2, pp. 138-150, 2011.

[87] S. Sadiq and G. Governatori, "Managing regulatory compliance in business processes," in Handbook on Business Process Management 2, pp. 265-288, Springer, Berlin, Germany, 2015.

[88] Tumiran, "Development of CMMS (Computerized Maintenance Management System) in Yogyakarta electric power distribution network company to support the strategic maintenance," in Proceedings of the 2008 International Conference on Condition Monitoring and Diagnosis, pp. 582-587, Beijing, China, April 2008.

[89] I. Abdullahi and W. Z. W. Yusoff, "Influence of facilities performance on student's satisfaction in northern nigerian universities: results from interim study," Facilities, vol. 37, no. 2, 2019.

[90] C. Parker, "Performance Measurement," Work Study, vol. 49, no. 2, 2000.

[91] J. M. Cupello, "A new paradigm for measuring TQM progress," Quality Progress, vol. 27, no. 5, pp. 79-82, 1994.

[92] P. Asubonteng, K. J. McCleary, and J. E. Swan, "SERVQUAL revisited: a critical review of service quality," Journal of Services Marketing, vol. 10, no. 6, 1996.

[93] A. E. Haddad, H. Al-Dmour, and Z. Al-Zu'bi, "Perceived service quality and customer satisfaction: an empirical investigation of the rebranded telecommunication companies in Jordan," European Journal of Social Sciences, vol. 34, no. 1, pp. 118-137, 2012.

[94] P. Khan and A. Tabassum, "Service quality and customer satisfaction of the beauty-care service industry in Dhaka: a study on high-end women's parlors," Journal of Business in Developing Nations, vol. 12, 2010.

[95] P. N. Muchiri, L. Pintelon, H. Martin, and A. M. D. Meyer, "Empirical analysis of maintenance performance measurement in Belgian industries," International Journal of Production Research, vol. 48, no. 20, pp. 5905-5924, 2010.

[96] K. Kutucuoglu, J. Hamali, Z. Irani, and J. Sharp, “A framework for managing maintenance using performance measurement systems," International Journal of Operations \& Production Management, vol. 21, no. 1/2, 2001.

[97] A. H. Eagly and S. Chaiken, The Psychology of Attitudes, Harcourt brace Jovanovich college publishers, CA, USA, 1993.

[98] A. Bandura and S. Wessels, "Self-efficacy," 1994.

[99] J. E. Maddux and J. T. Gosselin, Self-efficacy, The Guilford Press, NY, USA, 2012.

[100] R. M. Lee and S. B. Robbins, "Measuring belongingness: the social connectedness and the social assurance scales," Journal of Counseling Psychology, vol. 42, no. 2, pp. 232-241, 1995.

[101] K. Dartey-Baah, "Organizational antecedents and perceptions of fairness in policy implementation among employees in the banking sector of Ghana," African Journal of Business Management, vol. 8, no. 18, 2014.

[102] J. P. Meyer, N. J. Allen, and C. A. Smith, "Commitment to organisations and occupations: extension and test of a threecomponent conceptualization," Journal of Applied Psychology, vol. 78, pp. 538-551, 2003.
[103] A. Elmualim, D. Shockley, R. Valle, G. Ludlow, and S. Shah, "Barriers and commitment of facilities management profession to the sustainability agenda," Building and Environment, vol. 45 , no. 1 , pp. 58-64, 2010.

[104] D. Liptrot and G. Palarchio, "Utilizing advanced maintenance practices and information technology to achieve maximum equipment reliability," International Journal of Quality \& Reliability Management, vol. 17, no. 8, pp. 919928, 2000b.

[105] G. Fredriksson and H. Larsson, An Analysis of Maintenance Strategies and Development of a Model for Strategy Formulation, M Sc, Thesis, Chalmers University Of Technology, Göteborg, Sweden, 2012.

[106] D. Molochnikov, R. Khalimov, I. Gayaziev, D. Rudoy, and A. Olshevskaya, "The improvement of the technique for determining technical condition of repair and maintenance equipment," in Proceedings of the E3S Web of Conferences, vol. 210, Kryvyi Rih, Ukraine, May 2020.

[107] M. Engeler, D. Treyer, D. Zogg, K. Wegener, and A. Kunz, "Condition-based maintenance: model vs. Statistics a performance comparison,” Procedia CIRP, vol. 57, pp. 253-258, 2016.

[108] A. M. Crespo and J. N. D. Gupta, "Contemporary maintenance management: process, framework and supporting pillars," Omega, vol. 34, no. 3, pp. 313-326, 2006.

[109] R. Ruparathna, K. Hewage, and R. Sadiq, "Multi-period maintenance planning for public buildings: a risk based approach for climate conscious operation," Journal of Cleaner Production, vol. 170, pp. 1338-1353, 2018.

[110] A. M. Oliveira, I. d. S. Lopes, and D. Figueiredo, "Maintenance management practices of companies of the industrial pole of manaus," in Proceedings of the World Congress on Engineering and Computer Science 2014, San Fransisco, USA, 2014.

[111] D. Jandali, R. J. Sweis, and A. R. Alawneh, "Factors affecting maintenance OF hospital buildings: a literature review," Business Management, vol. 10, no. 3, 2018.

[112] A. Muchiri, B. Ikua, P. Muchiri, and P. Irungu, "Development of a theoretical framework for evaluating maintenance practices," International Journal of System Assurance Engineering and Management, vol. 8, no. 1, pp. 198-207, 2017.

[113] L. Pintelon and L. Van Wassenhove, "A maintenance management tool," Omega, vol. 18, no. 1, pp. 59-70, 1990.

[114] N. G. Gado and H. SamehHussien, "Work order management: a challenging tool towards successful hotel management," Journal Homepage, vol. 1, no. 41, pp. 110-114, 2019.

[115] M. J. Keneley, "The breakdown of the workplace 'family' and the rise of personnel management within an Australian financial institution 1950-1980," Business History, vol. 59, no. 2, pp. 250-267, 2017.

[116] D. Verma, "Service Level Agreements on IP Networks," 2004, http://www.research.ibm.com/people/d/dverma/ papers/SLAOverview.pdf.

[117] R. Edirisinghe, S. Sujeeva, G. Zhang, and W. Ron, "Council Building Management Practices, Case Studies and Road Ahead," in Engineering Asset Management and Infrastructure SustainabilityLondon, United Kingdom, 2011.

[118] Z.-A. Ismail, "System development toward effective maintenance management practices," Built Environment Project and Asset Management, vol. 4, no. 4, pp. 406-422, 2014.

[119] D. A. Harrison, D. A. Newman, and P. L. Roth, "How important are job attitudes? Meta-analytic comparisons of integrative behavioral outcomes and time sequences," 
Academy of Management Journal, vol. 49, no. 2, pp. 305-325, 2006.

[120] L. M. Saari and T. A. Judge, "Employee attitudes and job satisfaction," Human Resource Management, vol. 43, no. 4, pp. 395-407, 2004.

[121] I. S. Mohammad, N. N. Zainol, S. Abdullah, N. B. Woon, and N. A. Ramli, "Critical factors that lead to green building operations and maintenance problems in Malaysia," Theoretical and Empirical Researches in Urban Management, vol. 9, no. 2, pp. 68-86, 2014.

[122] D. Dukić, M. Trivunić, and A. C. Starčev, "Computer-aided building maintenance with "BASE-FM" program," Automation in Construction, vol. 30, pp. 57-69, 2013.

[123] M. Eyerusalem, Maintenance Management Framework Development for Competitiveness of Food and Beverage Industry: A Case Study on Asku PLC, Addis Ababa University, Addis Ababa, Ethiopia, 2018.

[124] A. W. Labib, "World-class maintenance using a computerised maintenance management system," Journal of Quality in Maintenance Engineering, vol. 4, no. 1, pp. 66-75, 1998.

[125] A. Parida, "Development of a multi-criteria hierarchical framework for maintenance performance measurement: concepts, issues and challenges," Doctoral thesis, Luleå tekniska universitet, Luleå, Sweden, 2006, http://urn.kb.se/ resolve?urn=urn:nbn:se:ltu:diva-25747\%20DiVA\%20database.

[126] S. N. Zubairu, "The national building maintenance policy for Nigeria: the architects' perspective," in Proceedings of the Compilation of Seminar Papers Presented at the 2010 Architects Colloquium-Architecture and the National Development, Abuja, Nigeria, April 2010.

[127] R. Farahani and M. G. Lipsett, "Framework for Design and Performance Evaluation of Effective Condition Monitoring and Maintenance Management Systems," eMaintenance, vol. 69, 2012.

[128] Y. A. Adewunmi, M. Omirin, and H. Koleoso, "Benchmarking challenges in facilities management in Nigeria," Journal of Facilities Management, vol. 13, no. 2, pp. 156-184, 2015a.

[129] K. Fraser, "Facilities management: the strategic selection of a maintenance system," Journal of Facilities Management, vol. 12, no. 1, pp. 18-37, 2014.

[130] F. N. Abdeen and Y. G. Sandanayake, "Facilities management supply chain: collaboration of FM functions, flows and parties in the apparel sector," International Journal of Logistics Research and Applications, pp. 1-20, 2020.

[131] A. D. Toni, A. Fornasier, and M. Montagner, "Open Facility Management: a new approach for the improvement of outsourced service industry," in Proceedings of the 14th EUROMA Conference: Managing Operations in an Expanding Europe), Ankara, Turkey, June 2007.

[132] B. S. Gandhare, M. M. Akarte, and P. P. Patil, "Maintenance performance measurement - a case of the sugar industry," Journal of Quality in Maintenance Engineering, vol. 24, no. 1, pp. 79-100, 2018.

[133] H. Alzaben, Development of a Maintenance Management Framework to Facilitate the Delivery of Healthcare Provisions in the Kingdom of Saudia Arabia, Nottingham Trent University, Nottingham, England, 2015.

[134] M. C. Eti, S. O. T. Ogaji, and S. D. Probert, "Reducing the cost of preventive maintenance (PM) through adopting a proactive reliability-focused culture," Applied Energy, vol. 83, no. 11, pp. 1235-1248, 2006 b.
[135] A. K. S. Jardine, D. Lin, and D. Banjevic, "A review on machinery diagnostics and prognostics implementing condition-based maintenance," Mechanical Systems and Signal Processing, vol. 20, no. 7, pp. 1483-1510, 2006.

[136] Z.-A. Ismail, "Maintenance management system (MMS) to support facilities management at Malaysian polytechnic," Smart and Sustainable Built Environment, vol. 6, no. 1, pp. 19-33, 2017.

[137] K. Panuwatwanich, Modelling the Innovation Diffusion Process in Australian Architectural and Engineering Design Organisations, Griffith University, Queensland, Australia, 2008.

[138] J. F. Hair Jr, M. Sarstedt, C. M. Ringle, and S. P. Gudergan, Advanced Issues in Partial Least Squares Structural Equation Modeling, saGe publications, CA, USA, 2017.

[139] K. J. Preacher and A. F. Hayes, "Asymptotic and resampling strategies for assessing and comparing indirect effects in multiple mediator models," Behavior Research Methods, vol. 40, no. 3, pp. 879-891, 2008.

[140] P. R. Mishra, G. Anand, and R. Kodali, "Development of a framework for world-class maintenance systems," Journal of Advanced Manufacturing Systems, vol. 5, no. 2, pp. 141-165, 2006.

[141] R. G. Amaratunga, Theory building in facilities management performance measurement: application of some core performance measurement and management principles, Ph.D. thesis, University of Salford, Salford, England, 2001.

[142] E. Saharkhiz, M. Bagherpour, M. R. Feylizadeh, and A. Afsari, "Software performance evaluation of a computerized maintenance management system: a statistical based comparison," Maintenance and Reliability, vol. 14, no. 1, pp. 77-83, 2012.

[143] H. H. A. Ghani, N. A. Hamid, S. Sanusi, and R. Shamsuddin, "The effect of tax knowledge, compliance costs, complexity and morale towards tax compliance among self-employed in Malaysia," Global Business and Management Research, vol. 12, no. 1, pp. 18-32, 2020.

[144] J. W. Creswell and J. D. Creswell, Research Design: Qualitative, Quantitative, and Mixed Methods Approaches, Sage publications, CA, USA, 2017.

[145] L. Colosi, "Designing an effective questionnaire," 2006.

[146] W. E. Saris and I. N. Gallhofer, Design, Evaluation, and Analysis of Questionnaires for Survey Research, John Wiley \& Sons, NJ, USA, 2014.

[147] H. Taherdoost, "Sampling Methods in Research Methodology; How to Choose a Sampling Technique for Research," SSRN Electronic Journal, vol. 5, no. 2, 2016.

[148] M. Sarstedt, C. M. Ringle, and J. F. Hair, "Partial least squares structural equation modeling," Handbook of market research, vol. 26, no. 1, pp. 1-40, 2017.

[149] G. T. M. Hult, J. F. Hair, D. Proksch, M. Sarstedt, A. Pinkwart, and C. M. Ringle, "Addressing endogeneity in international marketing applications of partial least squares structural equation modeling," Journal of International Marketing, vol. 26, no. 3, pp. 1-21, 2018.

[150] J. F. Hair, C. M. Ringle, and M. Sarstedt, "Partial least squares structural equation modeling: rigorous applications, better results and higher acceptance," Long Range Planning, vol. 46, no. 1-2, pp. 1-12, 2013.

[151] J. Hulland, "Use of partial least squares (PLS) in strategic management research: a review of four recent studies," Strategic Management Journal, vol. 20, no. 4, pp. 195-204, 1999. 
[152] R. P. Bagozzi, Y. Yi, and K. D. Nassen, "Representation of measurement error in marketing variables: review of approaches and extension to three-facet designs," Journal of Econometrics, vol. 89, no. 1-2, pp. 393-421, 1998.

[153] C. Fornell and D. F. Larcker, Structural Equation Models with Unobservable Variables and Measurement Error: Algebra and Statistics, Sage Publications Sage CA, Los Angeles, CA, 1981.

[154] D. Gefen, D. Straub, and M.-C. Boudreau, "Structural equation modeling and regression: guidelines for research practice," Communications of the Association for Information Systems, vol. 4, no. 1, 2000.

[155] J. C. Nunnally, "An overview of psychological measurement," in Clinical diagnosis of mental disorders, pp. 97-146, Boston, MA, USA, 1978.

[156] W. W. Chin, "The partial least squares approach to structural equation modeling," Modern methods for business research, vol. 295, no. 2, pp. 295-336, 1998.

[157] J. Cohen, Statistical Power Analysis for the Behavioural Sciences, Laurence Erlbaum Associates: Inc, Hillsdale, NJ, 1988.

[158] J. Henseler, C. M. Ringle, and R. R. Sinkovics, The Use of Partial Least Squares Path Modeling in International Marketing New Challenges to International Marketing, Emerald Group Publishing Limited, Bingley, United Kingdom, 2009.

[159] E. B. Aduwo, O. O. Akinwole, and P. O. Okpanachi, "Assessing workers' productivity through biophilic design as a measure of sustainability in selected office buildings in Lagos state, Nigeria," IOP Conference Series: Earth and Environmental Science, vol. 665, no. 1, Article ID 012047, 2021.

[160] R. Misiūnaitè, "Lietuvos Ir Užsienio Šaliụ Biurụ Paskirties Pastatų Ükio Valdymo Analizè," M Sc Thesis, Vilniaus Gedimino Technikos Universitetas, Vilnius, Lithuania, 2021.

[161] O. Adenuga, "Labour composition for maintenance works in public hospital built environment in south-west, nigeria," Journal of Building Performance, vol. 1, no. 1, 2010. 